\title{
Large-Bore Pipe Decontamination
}

\author{
Topical Report \\ January 1998
}

\author{
By: \\ M. A. Ebadian
}

Work Performed Under Contract No.: DE-FG21-95EW55094

For

U.S. Department of Energy Office of Fossil Energy

Federal Energy Technology Center

P.O. Box 880

Morgantown, West Virginia 26507-0880
RECEIVES

OCT 201998

OSTI

By

Florida International University

Hemispheric Center for Environmental Technology (HCET)

Center for Engineering \& Applied Sciences

10555 West Flagler Street

EAS-2100

Miami, Florida 33174 


\section{Disclaimer}

This report was prepared as an account of work sponsored by an agency of the United States Government. Neither the United States Government nor any agency thereof, nor any of their employees, makes any warranty, express or implied, or assumes any legal liability or responsibility for the accuracy, completeness, or usefulness of any information, apparatus, product, or process disclosed, or represents that its use would not infringe privately owed rights. Reference herein to any specific commercial product, process, or service by trade name, trademark, manufacturer, or otherwise does not necessarily constitute or imply its endorsement, recommendation, or favoring by the United States Government or any agency thereof. The views and opinions of authors expressed herein do not necessarily state or reflect those of the United States Government or any agency thereof. 


\section{DISCLAIMER}

Portions of this document may be illegible electronic image products. Images are produced from the best available original document. 
This report is based on work supported by the U.S. Department of Energy, Office of Environmental Management, Office of Science and Technology's Deactivation and Decommissioning Focus Area, Federal Energy Technology Center. The Principal Investigator, Florida International University (FIU) Collaborators, and students at FIU would like to thank Dr. Paul Hart and Steve Bossart for providing us with the opportunity and support to work on this project. The FIU Collaborators would also like to thank Diane Toro for her hard work and support in the completion of this project. 


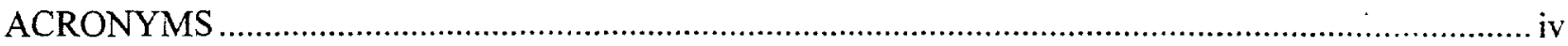

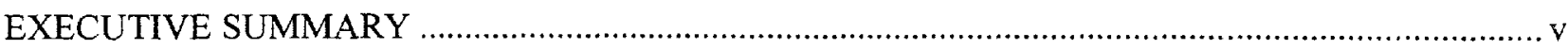

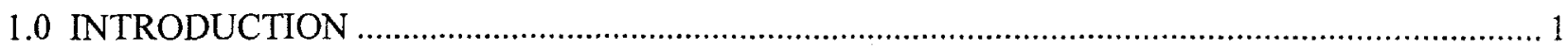

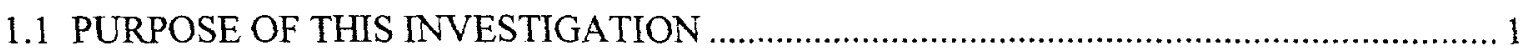

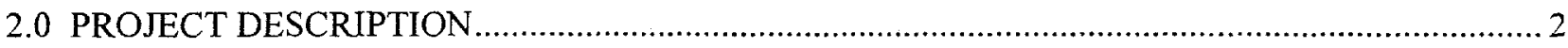

3.0 RESULTS

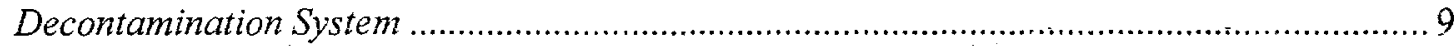

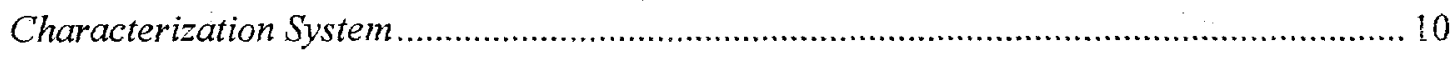

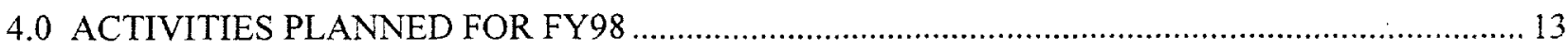

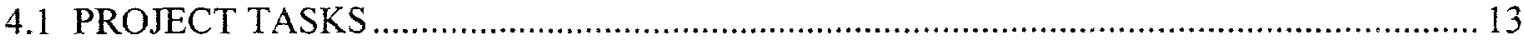

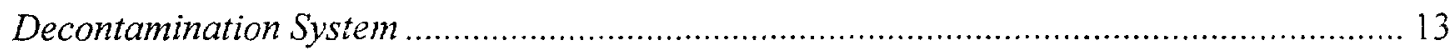

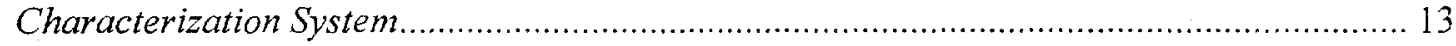

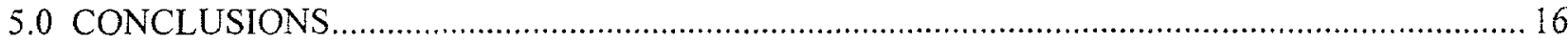

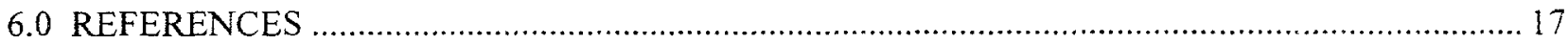

APPENDIX A

APPENDIX B 


\section{ACRONYMS}

D\&D Decontamination and Decommissioning

DOE U.S. Department of Energy

DOE-EM U.S. Department of Energy-Environmental Management

DOE-OST U.S. Department of Energy-Office of Science and Technology

FIU Florida International University

FIU-HCET Florida International University-Hemispheric Center for Environmental Technology

FY97 Fiscal Year 1997

FY98 Fiscal Year 1998

HCET Hemispheric Center for Environmental Technology

RAPIC Remedial Action Program Information Center 
The decontamination and decommissioning (D\&D) of 1200 buildings within the U.S. Department of Energy-Office of Environmental Management (DOE-EM) Complex will require the disposition of miles of pipe. The disposition of large-bore pipe, in particular, presents difficulties in the area of decontamination and characterization. The pipe is potentially contaminated internally as well as externally. This situation requires a system capable of decontaminating and characterizing both the inside and outside of the pipe. Current decontamination and characterization systems are not designed for application to this geometry, making the direct disposal of piping systems necessary in many cases. The pipe often creates voids in the disposal cell, which requires the pipe to be cut in half or filled with a grout material. These methods are labor intensive and costly to perform on large volumes of pipe. Direct disposal does not take advantage of recycling, which could provide monetary dividends. To facilitate the decontamination and characterization of large-bore piping and thereby reduce the volume of piping required for disposal, a detailed analysis will be conducted to document the pipe remediation problem set; determine potential technologies to solve this remediation problem set; design and laboratory test potential decontamination and characterization technologies; fabricate a prototype system; provide a cost-benefit analysis of the proposed system; and transfer the technology to industry.

This report summarizes the activities performed during fiscal year 1997 (FY97) and describes the planned activities for fiscal year 1998 (FY98). Accomplishments for FY97 include the development of the applicable and relevant and appropriate regulations, the screening of decontamination and characterization technologies, and the selection and initial design of the decontamination system. 


\subsection{INTRODUCTION}

The D\&D of 1200 buildings in the DOE-EM Complex will require the disposition of miles of pipe. This pipe ranges in size, material type, type of contaminant, and coating. The disposition of large-bore pipe presents difficulties in the areas of decontamination, characterization, and disposition. The pipe is potentially contaminated internally as well as externally. This situation requires a system capable of decontaminating and characterizing the interior and exterior of the pipe. Current decontamination and characterization systems are not designed to do both, necessitating, in many cases, direct disposal of piping systems. The pipe creates voids in the disposal container and in the disposal cell, requiring the pipe to be cut in half or filled with a grout material. These methods are labor intensive and costly to perform on large volumes of pipe: Also, direct disposal does not take advantage of recycling, which would provide monetary dividends during the disposition of large-bore pipe.

\subsection{PURPOSE OF THIS INVESTIGATION}

The decontamination and characterization of large-bore pipe is difficult because of the various geometries and diameters of pipe and its different material types. A robust decontamination system must be capable of adapting to different pipe diameters (project scope is 6 inches to 24 inches), cleaning surfaces with various surface conditions and material types (i.e., painted, rusted, carbon steel, or stainless steel) and be cost effective to operate and maintain. The characterization system must be capable of handling the different pipe parameters and detecting contamination on the inside and outside surfaces to meet the criteria for unrestricted reuse. It must also operate in a cost-effective manner. Current technology options do not provide a robust system to meet these objectives.

The purpose of this project is to verify the need for this technology through determining quantities of pipe available for decontamination, perform a technology screening process to select technologies for decontamination and characterization, perform treatability studies to collect required performance data, and design and fabricate a prototype system to decontaminate the internal and external surfaces of large-bore pipe. A field mobile system capable of performing decontamination and characterization operations will be the main deliverable for this project. 


\subsection{PROJECT DESCRIPTION}

The following tasks were scheduled for completion during FY97. Throughout this process, remediation service companies have been involved to ensure the large-bore pipe system is commercially viable and that a system will be marketed upon satisfactory testing. The preliminary engineering tasks (Tasks I-VI) were performed during FY97, with the majority of the fabrication and evaluation activities (Task VII) to occur during FY98.

TASK I. PERFORM A LITERATURE SEARCH AND SURVEY THE D\&D COMMUNITY TO DETERMINe THE PIPE REMEDIATION PROBLEM SET

Task II. Develop a Problem Statement Detailing the Pipe Remediation Problem Set

TASK III. Determine APPliCable Regulatory Policies AND Procedures

Task IV. Perform a Review of Pipe decontamination and Characterization Systems and DEVELOP SYSTEM DESCRIPTIONS

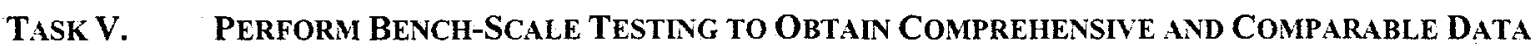

TASK VI. PERFORM LIFE-CYCLE COST ANALYSIS OF VIABLE SYSTEMS (FY97-FY98)

TASK VII. DEVELOP A LABORATORY-SCALE SYSTEM (FY 97-FY98) 


\subsection{RESULTS}

The seven tasks presented in Section 2 "Project Description" and in the FY97 Project Technical Plan (PTP) are presented below. The italicized text indicates the task description presented in the FY97 PTP. The results of each task and any deviations are presented in the paragraphs that follow.

The planned activities for FY97, with the exception of selecting the characterization technology and the completion of the life-cycle cost assessment, were completed on schedule. The selection of the characterization technology will be completed during December 1997 and January 1998, and the life-cycle cost assessment will not occur until after the initial design of the characterization system is completed. The delay in the life-cycle cost analysis is due to the fact that required cost numbers are not available for these unique systems until well into the design stage. However, preliminary cost numbers will be obtained and reviewed during the first quarter of 1998 to ensure the system will be a cost-effective option. The delay in the selection of the characterization system is due to the fact that gathering the technology screening information for the characterization technologies was a time-consuming task extending beyond its planned duration.

TASK I. PERform a LiTERATURE SEARCh AND SURVEY THE D\&D COMmunity to Deternine THe PIPE Reviediation Problem SeT

To ensure the applicability of the system, a detailed analysis will be conducted to define the pipe remediation problem set. This will include conducting a literature search and contacting the Site Technology Coordination Groups (STCGs) at the DOE sites to define the magnitude and scheduling constraints for pipe remediation. Information related to pipe diameter, material of construction, contaminants of concern, and the availability of the material for $D \& D$ will be compiled. This information will be studied to ensure that the system resolves the existing problem set.

The objective of this task was to provide potential commercial partners with quantities and schedule information related to the pipe remediation problem set. Through initial contacts and previous experiences with trying to obtain quantities and other information related to remediation waste quantities from DOE sites, this task was simplified to reviewing sites with known published information related to remediation waste quantities. Through this review, Hanford reported $150,000 \mathrm{~m}^{3}$, and Fernald reported $6,000 \mathrm{~m}^{3}$ of piping. If the average pipe diameter is assumed to be $10 \mathrm{in}$., then $1 \mathrm{ft}$ of pipe is $0.5454 \mathrm{ft}^{3}$. Therefore, approximately 10 million linear feet of piping will require disposition. The decontamination system's projected average production rate for 10-in.-diameter pipe is $1 \mathrm{ft}$ per minute; therefore, approximately 168,000 hours of processing will be required. If the unit operates 2,000 hours per year, the system will be run for 84 years to complete the quantities reported by these two remediation sites. Additional sites are currently performing D\&D and will generate quantities of pipe requiring disposition; therefore, it is projected that the system would be implemented for an extended period of time if it is proven cost effective and reliable. 


\section{TASK II. DEVEloP A PROBLEM}

\section{Statement Detailing the Pipe Remediation Problem Set}

A detailed project statement specifying the requirements for the decontamination and characterization system will be developed. This project statement will be used to develop the specifications for the decontamination and characterization system. These specifications will dictate the specific contaminants of concern and the applicable diameters and construction materials the system is capable of processing. This problem statement will be used to develop potential decontamination and characterization systems.

Based on the information found in Task 1 and on the D\&D experience of project team members, the problem statement was developed for the decontamination and characterization system. The problem statement is as follows:

The scope of the project entails delivering a field-ready mobile system to process large-bore pipe creating a near-white metal finish on the internal and external surfaces. The pipe ranges in diameter from 6 in. to $24 \mathrm{in}$. The maximum length of material to be cleaned by the system is ten feet. All obstructions, valves, and flanges will be removed from the pipe prior to entering the decontamination system. The minimum system requirements include:

- The system must be capable of achieving a near-white metal finish ${ }^{1}$ on the interior and exterior of the pipe.

- The system must handle pipes 6 in. to 24 in. in diameter.

- The system must handle pipes up to $10 \mathrm{ft}$ in length.

- The output of the system must produce a surface that is free of moisture and dust.

- The process rate must be 3 to $5 \mathrm{ft}$ per minute for 6 -in.-diameter pipe.

- The ventilation system must follow ANSI 509 and 510 standards for nuclear systems.

- The system must have nuclear grade bag-in bag-out HEPA filtration as the final stage of. filtration.

- All spent media and waste from the pipe must be collected in standard 55-gal drums.

- All waste must be dry and be considered non-hazardous as contained in 55-gal drums.

- System components must fit inside a nuclear grade strong tight container or containers.

- The system must be completely field mobile.

- All electrical work must meet Occupational Safety and Health Association (OSHA) standards and must be watertight.

- The system must include 15 -ft-long entry and exit material handling systems.

\footnotetext{
1 "A cleaned, near-white surface, when viewed without magnifications, shall be free of all visible oil, grease, dirt, dust, mill scale, rust, paint and oxides, corrosion products and other foreign matter, except for staining. Staining shall be limited to no more than five percent of each square inch of the surface area and may consist of light shadows, slight streaks or minor discolorations caused by rust stains, mill scale stains, or previously applied paint stains." (Structural Steel Painting Council, 1991, Surface Preparation Specifications, Structural Steel Painting Council, Pittsburgh, PA, pp. 53-56.)
} 
- The system must meet the requirements for unrestricted reuse as defined in DOE Order 5400.5 and Regulatory Guide 1.86.

\section{TASK III. Determine APPliCABle Regulatory Policies AND Procedures}

To ensure the applicability of the system, a complete review will be conducted to determine the relevant regulatory policies and procedures for its development and implementation. Areas of concern include, but are not limited to, transportation of the system, air emissions during operation, acceptance criteria for the release of the decontaminated pipe, and health and safety issues associated with operating the equipment. During the design and fabrication of the system, a complete list of applicable regulations will be compiled along with the details regarding the manner in which the regulations will be met.

Table 1 presents the applicable, relevant, and appropriate regulations (ARARs) to be considered for the design and construction of the decontamination and characterization system. The ARARs have been presented to vendors and subcontractors for use during the completion of various phases of this project.

Table 1.

Applicable and Relevant and Appropriate Regulations (ARARs)

\begin{tabular}{|l|l|}
\hline Source & Description \\
\hline 40 CFR 260.10 & Definition of remediation waste \\
\hline 40 CFR 261.3 & $\begin{array}{l}\text { Resource Conservation and Recovery Act (RCR.4) hazardous } \\
\text { waste determination data }\end{array}$ \\
\hline 40 CFR $261.3($ a) & Definition of hazardous waste \\
\hline 40 CFR 261.6 & Requirements for recyclable materials \\
\hline 40 CFR 262.20 through $.33,40$ CFR 263.20 & RCRA preparing and transporting hazardous waste off-site \\
\hline 40 CFR 265.171 through .174, .176 and .177 & RCRA condition of containers \\
\hline 40 CFR 268.2 & RCRA definition of hazardous waste debris \\
\hline 40 USC $\$ 4901$ et seq. & Noise control \\
\hline 40 USC $\$ 6903(27)$ & Definition of solid waste \\
\hline 42 USC $\$ 10101(12),(16),(23)$ & Nuclear Waste Policy Act \\
\hline 42 USC $\$ 2014(2)(e e)$ & $\begin{array}{l}\text { Atomic Energy Act definition of low-level radioactive } \\
\text { material }\end{array}$ \\
\hline 42 USC $\S 7641$ & Noise Pollution and Abatement Act \\
\hline
\end{tabular}


Table 1.

Applicable and Relevant and Appropriate Regulations (ARARs) (Continued)

\begin{tabular}{|c|c|}
\hline \multicolumn{2}{|l|}{ RADIOACTIVE } \\
\hline 10 CFR 1021.2 & $\begin{array}{l}\text { Provides requirements for complying with National } \\
\text { Environmental Protection Act (NEPA) at DOE facilities. }\end{array}$ \\
\hline 10 CFR 20 & $\begin{array}{l}\text { Defines the Nuclear Regulatory Commission's (NRC's) } \\
\text { standards for protection against radiation hazards. Subpart B } \\
\text { provides the protection program. Subparts C and D provide } \\
\text { dose limits. Subpart E (proposed) provides radiological } \\
\text { criteria for decommissioning. Subpart H provides information } \\
\text { on respiration protection and controls to restrict internal } \\
\text { exposure in restricted areas. Subpart K provides information } \\
\text { on waste disposal. }\end{array}$ \\
\hline 10 CFR 835 & Occupational radiation protection \\
\hline 40 CFR $191.03(b)$ & $\begin{array}{l}\text { Environmental Radiation Protection Standards for } \\
\text { Management and disposal of high-level radioactive waste } \\
\text { (HLRW), spent nuclear fuel and transuranic (TRU) wastes }\end{array}$ \\
\hline 40 CFR 191.13 through .15 & $\begin{array}{l}\text { Environmental radiation protection standards for the } \\
\text { management and disposal of HLRW, spent nuclear fuel, and } \\
\text { TRU wastes }\end{array}$ \\
\hline DOE Order 441.1 & $\begin{array}{l}\text { Standards for occupational radiation protection of workers at } \\
\text { DOE facilities }\end{array}$ \\
\hline DOE Order 5400.5 & $\begin{array}{l}\text { Radiological protection requirements and guidelines for the } \\
\text { cleanup of residual radioactive materials and the management } \\
\text { of the resulting waste and residues and release of property }\end{array}$ \\
\hline DOE Order $6430.1 \mathrm{~A}, 1324-5.3,-6$ & $\begin{array}{l}\text { Low-level radioactive solid waste confinement (general } \\
\text { design criteria) }\end{array}$ \\
\hline Reg. Guide 1.86 & $\begin{array}{l}\text { Section four of this document provides surface } \\
\text { decontamination limits for release for unrestricted use. }\end{array}$ \\
\hline \multicolumn{2}{|l|}{ AIR } \\
\hline 40 CFR $264.1030 ; .1032$ through .1034 & Permitted status: air emission standards for process vents \\
\hline 40 CFR $60.672(a),(d),(e)$ & $\begin{array}{l}\text { Standards of performance for nonmetallic mineral processing } \\
\text { plants }\end{array}$ \\
\hline Clean Air Act & $\begin{array}{l}\text { General provision on air pollution control prevention of air } \\
\text { pollution nuisance }\end{array}$ \\
\hline
\end{tabular}


Table 1.

Applicable and Relevant and Appropriate Regulations (ARARs) (Continued)

\begin{tabular}{|c|c|}
\hline \multicolumn{2}{|c|}{ HAZARDOUS WASTE MANAGEMENT (TRANSPORTATION) } \\
\hline 10 CFR 71 & $\begin{array}{l}\text { Provides requirements that must be used in the packaging } \\
\text { and transportation of radioactive material }\end{array}$ \\
\hline 40 CFR $262.20-262.33$ and 263.20 through 263.31 & $\begin{array}{l}\text { Generators who transport hazardous waste for off-site } \\
\text { treatment, storage, and disposal }\end{array}$ \\
\hline 49 CFR $171-173,177,178$ & $\begin{array}{l}\text { Department of Transportation requirements for the } \\
\text { transportation of hazardous materials }\end{array}$ \\
\hline 49 USC $\$ 1801-1812$ & Hazardous Materials Transportation Act \\
\hline 49 CFR 171 & $\begin{array}{l}\text { Prescribes requirements governing transportation of } \\
\text { hazardous material and the manufacture and packaging of } \\
\text { containers }\end{array}$ \\
\hline 49 CFR 172 & $\begin{array}{l}\text { Prescribes requirements for shipping papers; package } \\
\text { marking, labeling, and placarding; and emergency response } \\
\text { and training }\end{array}$ \\
\hline 49 CFR 173 & $\begin{array}{l}\text { Includes definitions of hazardous materials, package } \\
\text { preparation requirements, and inspection and testing } \\
\text { responsibilities }\end{array}$ \\
\hline 49 CFR 174 & $\begin{array}{l}\text { Prescribes requirements for the transport of hazardous } \\
\text { materials in or on rail cars }\end{array}$ \\
\hline 49 CFR 175 & $\begin{array}{l}\text { Prescribes requirements for the transport of hazardous } \\
\text { material aboard aircraft }\end{array}$ \\
\hline 49 CFR 176 & $\begin{array}{l}\text { Prescribes requirements for the transport of hazardous } \\
\text { materials by vessel }\end{array}$ \\
\hline 49 CFR 177 & $\begin{array}{l}\text { Prescribes requirements for the transport of hazardous } \\
\text { material by motor vehicle }\end{array}$ \\
\hline DOE Order $1540.1 \mathrm{C}$ & $\begin{array}{l}\text { This order establishes the DOE's polices for management of } \\
\text { materials transportation. }\end{array}$ \\
\hline DOE Order 1540.2 & $\begin{array}{l}\text { Standardizes the current approval procedures to ensure that } \\
\text { DOE packaging designs and transportation operation provide } \\
\text { for public health and safety in accordance with regulations } \\
\text { of the DOT and in accordance with standards that are } \\
\text { equivalent to the standards prescribed by NRC }\end{array}$ \\
\hline & $\begin{array}{l}\text { Chapters II through Chapter XII of this Order summarize the } \\
\text { actions associated with the review and approval of } \\
\text { packaging for the transportation of radioactive and other } \\
\text { hazardous materials. }\end{array}$ \\
\hline DOE Order $1540.3 \mathrm{~A}$ & $\begin{array}{l}\text { Provides definitions used in transportation and packaging of } \\
\text { radioactive materials }\end{array}$ \\
\hline DOE Order $5480.3 \mathrm{~A}$ & Hazardous materials packaging and transportation safety \\
\hline
\end{tabular}


Table 1.

Applicable and Relevant and Appropriate Regulations (ARARs) (Continued)

\begin{tabular}{|c|c|}
\hline \multicolumn{2}{|l|}{ Other Requirements } \\
\hline 10 CFR 61 & $\begin{array}{l}\text { Provides requirements for the land disposal of radioactive } \\
\text { waste }\end{array}$ \\
\hline 29 CFR 1904 and 1910 & OSHA worker protection requirements \\
\hline Clean Water Act & $\begin{array}{l}\text { General provision on water pollution control prevention of } \\
\text { water pollution nuisance }\end{array}$ \\
\hline DOE $5700.6 \mathrm{C}$ & Quality assurance \\
\hline DOE Order $5440.1 \mathrm{E}$ & NEPA compliance program \\
\hline DOE Order $5480.1 \mathrm{~B}$ & $\begin{array}{l}\text { Environmental, safety, and health program for DOE } \\
\text { operations }\end{array}$ \\
\hline DOE Order 5480.4 & $\begin{array}{l}\text { Environmental protection, safety, and health protection } \\
\text { standards }\end{array}$ \\
\hline DOE Order $5483.1 \mathrm{~A}$ & $\begin{array}{l}\text { Occupational safety and health programs for DOE } \\
\text { employees at government-owned, contractor-operated } \\
\text { facilities }\end{array}$ \\
\hline DOE Order $6430.1 \mathrm{~A}$ & General design criteria \\
\hline
\end{tabular}

Sources: . DOE/EM-0246 U.S. Department of Energy, 1995, Decommissioning Resource Manual, U.S. DOE, Germantown, MD, Appendix E.

U.S. Department of Energy, Draft 4, 1996, Preferred Decommissioning Technologies Guide, U.S. DOE, Germantown, MD.

TASK IV. PERform a ReVIew of PIPE DeContamination AND CHARACTERIZATION SYSTEMS AND DEVELOP SYSTEM DESCRIPTIONS

Using the problem statement and specifications developed as part of Task II, a review will be conducted of the previous work performed in the area of ex-situ decontamination and characterization for piping systems. System descriptions will then be developed for each viable alternative. The information required for a life-cycle cost analysis will be gathered as part of this review. This information includes capital cost, operations and maintenance cost, system life, disposal costs, and secondary waste management costs. This information will be validated to ensure that the costs are an accurate representation of the actual costs. Information related to end points achieved, health and safety issues, production rates, sensitivity levels for sensors, availability of the equipment, field portability, utility requirements, and training requirements will also be gathered as part of this review.

Established sources and databases were used for categorizing and performing the initial technology screening. These sources and databases included the following:

- DOE/EM-0142P Decommissioning Handbook

- ORNL/M-2751 Oak Ridge National Laboratory Technology Logic Diagram 
- EGG-WTD-11104 Idaho National Engineering Laboratory Decontamination and Decommissioning Technology Logic Diagram

- DOE-EM, 1996, Draft-4, Preferred Decommissioning Technologies Guide

- UC-706 Hemispheric Center for Environmental Technology, 1995, Analysis of Potential Surface Blasting Decontamination Technologies for Structural Steel

- Hemispheric Center for Environmental Technology (HCET), Draft January 1997, Analysis of Potential Concrete Floor Surface Removal Technologies

- Remedial Action Program Information Center (RAPIC) database

- Nuclear News Buyers Guide

- Fernald Environmental Restoration Management Corporation (FERMCO), 1993, Operable Unit 3 Remedial Investigation and Feasibility Study Work Plan Addendum, Final

\section{Decontamination System}

The screening tables for the decontamination system are presented in Appendix A. The tables include technologies that have been eliminated from further review during the initial screening process. After the initial screening, six technologies were retained for further evaluation. The further evaluation consisted of performing a detailed review to determine if the technologies were feasible given the project parameters. The technologies included for further review were the following:

- Automated grinding

- Laser ablation

- Flashlamp

- Ultrasonic cleaning

- Grit blasting

- Shot blasting

After the completion of bench scale testing (Task V), laser ablation and automated grinding were eliminated from future consideration. Flashlamp, ultrasonic cleaning, and shot blasting were eliminated after the completion of a more detailed literature review. The flashlamp technology was eliminated because it was not able to meet the requirements for a near-white metal finish. Ultrasonic cleaning was eliminated because of the requirement to be a field-mobile system and not being able to meet a near-white metal finish without creating a potential mixed waste. Shot blasting was eliminated because of the possibility of trapping the contamination within the peened over metal surfaces causing difficulty in completing the characterization effort.

Based on the initial screening, grit blasting was selected as the decontamination technology for the internal and external surfaces of the pipe. Grit blasting is a proven commercial technology that is aggressive, generates very little secondary waste, can be adjusted to meet a variety of surface finish 
requirements (including near-white metal), does not produce an aqueous or hazardous waste, and can be developed into a field-mobile system.

\section{Characterization System}

The literature search and screening for possible technology alternatives for pipe characterization systems are presented in Appendix B. The completion of this task was more time consuming than planned. Screening of the alternatives and the development of the required procurement documents have been scheduled for completion during FY98.

\section{TASk V. Perform BenCh-SCAle Testing to Obtain Comprehensive and COMPaRable Data}

If the results of the initial screening indicate a lack of performance data on the decontamination and characterization systems, field and laboratory testing of the decontamination and characterization system will be conducted as required. This development and testing program will ensure that comprehensive and comparable data is available to conduct a thorough review of the systems. Benchscale testing will be used to validate the end point achieved, production rates, health and safety issues, and operations and maintenance issues.

Carbon steel samples were sent to two laser ablation vendors to obtain an indication of whether laser ablation can achieve a near-white metal finish on a painted carbon steel surface. Both vendors' results were similar, indicating the surface could not be cleaned to a near-white metal surface with the laser systems they used. Based on this review, laser ablation was eliminated from further consideration.

The manufacturer-recommended honing devices for 4-in., 6-in., and 10-in. diameter pipes were obtained from Brush Research Manufacturing Company and evaluated on non-contaminated carbon steel at the HCET test facility. The device was operated inside the test pipe as directed by the manufacturer. The technology was able to achieve a near-white metal finish; however, the honing device showed excessive wear and would not be practical for high volume, high production rate applications.

Based on these bench-scale tests, laser ablation and the honing device were eliminated from further consideration.

\section{TASK VI. PeRform Life-CYCle COST ANALYSIS OF Viable SySTEMS}

A life-cycle cost analysis will be performed using the data on the viable options for the decontamination and characterization of large-bore pipe. As part of the completion of the life-cycle cost analysis, assumptions related to labor rates, disposal costs, and project schedule will be developed. A sensitivity analysis will be conducted to determine the acceptability of the life-cycle cost analysis for the different DOE sites. Based on the results of the life-cycle cost analysis, the decontamination and characterization systems will be selected.

The completion of the initial screening process for the decontamination system produced one viable alternative-grit blasting. Life-cycle cost analysis worksheets were distributed to five different grit blasting vendors requesting the necessary information and backup data to complete a life-cycle cost analysis. The response from the vendors was incomplete and inadequate to 
perform a life-cycle cost analysis. Further information was requested from the vendors, but the responses again were inadequate. The decision was made to proceed with the procurement process and obtain the necessary information as part of the requirements of submitting a responsible bid. The information obtained from the bidders was appropriate to perform an initial cost analysis; however, the data could not be used in a life-cycle cost analysis because the data could not be verified. Variables defined during the completion of the initial design would provide the necessary level of detail to perform a life-cycle cost analysis. The initial design of the decontamination system is complete, and the required information to perform a life-cycle cost analysis is available. However, this task will be delayed until the completion of the initial design of the characterization system, which is planned for the first quarter of FY98. Delaying this task will allow a total system life-cycle cost analysis to be developed.

\section{TASK VII. DEVELOP LABORATORY-SCALE SYSTEM}

Using the results of the life-cycle cost analysis and the review of issues associated with fabrication, operations, and health and safety issues, a laboratory-scale system will be developed. The laboratoryscale system will be of sufficient scale to ensure that all operations and maintenance issues are reviewed. The laboratory scale system will include a HEPA ventilation system, material handling equipment, a pipe decontamination system, and a pipe characterization system. The testing of this system will include the processing of five tons of pipe. Based on the results of the laboratory testing, a full-scale system design including a field-mobile system capable of characterizing and decontaminating large-bore pipe applicable to the most viable problem set within the DOE Complex will be developed and transferred to industry. It is anticipated that the laboratory-scale system and the full-scale system design will continue through FY98.

A scope of work to design, fabricate, and test the decontamination system was developed and sent to five different grit blasting vendors. The proposals received were all of equal quality; therefore, the vendor with the lowest bid was selected, and a purchase order has been issued to the company. The system consists of three main components: a centrifugal wheel grit blasting machine for performing external decontamination, a lance-type system for internal decontamination, and a ventilation component. The initial design, final design, fabrication, and testing of the decontamination system have been scheduled for completion during FY98. Section 4, "Planned FY98 Activities," outlines the tasks scheduled for completion for the decontamination and characterization systems.

Figure 1 shows the general layout of the system and its different modules. 


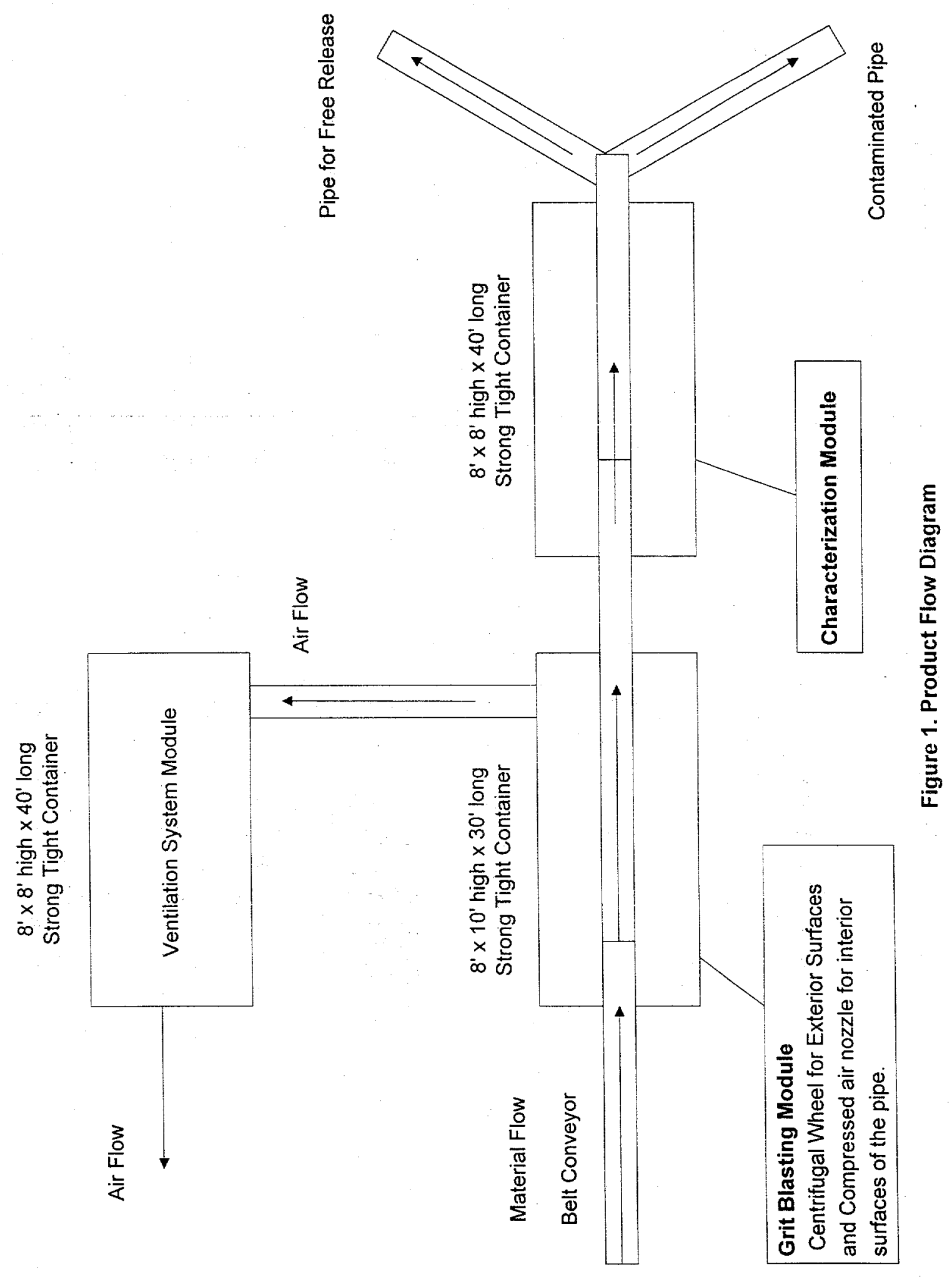




\subsection{ACTIVITIES PLANNED FOR FY98}

The following tasks are scheduled for completion during FY98. The project tasks have been grouped into three categories: decontamination system, characterization system, and integration of the two systems.

\subsection{PROJECT TASKS}

\section{Decontamination System}

TASK 1. TITLE I DESIGN

An initial design of the system and a review of the estimated costs for its completion will be performed. Florida International University-HCET (FIU-HCET) will review and approve 20\% completion of design drawings. FIU-HCET will also approve the expenditure for long lead-time procurement items. (Completed 11/97)

\section{TASK 2. TITLE II DESIGN}

FIU-HCET will review and approve the final design of the large-bore pipe cleaning system and review the estimated costs for its completion.

\section{TASK 3. TITLE III DESIgN}

FIU-HCET will monitor the fabrication of the system to ensure that the specifications and design drawings are being followed.

\section{TASK 4. OPERATIONS}

FIU-HCET will witness the cleaning of five tons of pipe ranging from 6 in. to $24 \mathrm{in}$. in diameter. The vendor will develop a detailed operations and maintenance manual. Remediation service companies will be invited to the system testing to offer input and to help determine potential technology transfer partners.

\section{TASK 5. Close-OUT}

Upon successful field-testing, the system will be transported to FIU-HCET, and five people will be trained on the operation and maintenance of the system.

\section{Characterization System}

\section{TASK 1. SCREen Potential ChaRaCterization TeChNologies}

A detailed review will be performed on the preliminary list of characterization technologies to determine the viable technology options. This assessment may involve laboratory testing of technologies in which detailed performance data is required to ensure the viability of the system. The technologies that pass the screening process will be part of the bidders list for the request for proposal. 


\section{TASK 2. DESIGN AND Evaluate EIC TeChNology}

The EIC technology will be further developed for application to characterizing the internals of pipe. This includes reviewing the system from a fluid mechanics view point, evaluating the system at different flow rates, and evaluating different radioactive sources and dimensions of pipe. Equipment parameters will be reviewed to ensure the system has the appropriate limits of detection and production rates along with other performance factors.

\section{TASK 3. Procurement of Characterization System}

Detailed performance specifications will be developed, and a request for proposal will be developed and sent to the potential vendors. At a minimum, the specifications will detail minimum detection limits, contaminants of concern, production rates, and deployment requirements. Based on the bid responses; the vendor that presents the least cost option that meets the performance specifications will be selected to design, fabricate, and test the characterization system under the oversight of HCET.

\section{TASK 4. TITLE I DESIGN}

Title I design will require the development of initial design drawings and the approval of longterm procurement items.

\section{TASK 5. TITLE II DESIGN}

FIU-HCET will review and approve the final design of the characterization system and review estimated costs for completion.

\section{TASK 6. TITLE III DESIGN}

FIU-HCET will monitor the fabrication of the system to ensure the specifications and design drawings are being followed.

\section{TASK 7. OPERATIONS}

FIU-HCET will witness the characterization of five tons of pipe ranging from $6 \mathrm{in}$. to $24 \mathrm{in}$. in diameter: A detailed operations and maintenance manual will be developed by the vendor for the calibration and operation of the characterization system. Remediation service companies will be invited to the system testing to offer input and to help determine potential technology transfer partners.

\section{TASK 8. CLOSE-OUT}

Upon successful field-testing, the system will be transported to FIU-HCET, and five people will be trained on the operation and maintenance of the characterization system.

\section{TASK 9. INTEGRATE DECONTAMINATION AND CHARACTERIZATION SYSTEMS}

The decontamination and characterization system will be integrated during all steps of the design and fabrication of the two main systems. Prior to field implementation at a DOE site, the systems will be tested to ensure all material handling, power, and layout issues are resolved so the system 
will operate as an integrated system. The system will be operated at the HCET test facility to complete this task.

\section{TASK 10. Field IMPLEMENTATION AT A SELECTEd DOE SITE.}

With the help of the D\&D Focus Area manager, a DOE remediation project will be selected to operate the system on a minimum of ten tons of pipe. Remediation service companies will be invited to the system testing to offer input and to help finalize potential technology transfer partners. 


\subsection{CONCLUSIONS}

The project tasks for FY97 have been completed within budget and on schedule with the exception of the selection of the characterization system and the completion of the life-cycle cost analysis. These activities will be completed during FY98 with no change in the project completion date of October 1998. Through the selection and initial design of the decontamination technology, the project shows the promise of producing a cost-effective alternative to the direct disposal of piping systems. 


\subsection{REFERENCES}

Fernald Environmental Restoration Management Corporation (FERMCO), 1994, Operable Unit 3 Treatability Study Work Plan, FERMCO, Cincinnati, Ohio.

Fernald Environmental Restoration Management Corporation (FERMCO), 1993, Operable Unit 3 Remedial Investigation and Feasibility Study Work Plan Addendum, Final, U.S. Department of Energy, Cincinnati, Ohio.

Idaho National Engineering Laboratory (INEL), January 1994, Idaho National Engineering Laboratory Decontamination and Decommissioning Technology Logic Diagrams, U.S. DOE, EGG-WTb-11104, EG\&G Idaho, Inc., Idaho Falls, Idaho.

Oak Ridge National Laboratory (ORNL), 1993, Oak Ridge National Laboratory Technology Logic Diagram, ORNL/M-2752, U.S. Department of Energy, Oak Ridge, Tennessee.

U.S. Department of Energy, 1994, Decommissioning Handbook, DOE/EM-0142P.

U.S. Department of Energy, 1990, Radiation Protection of the Public and the Environment, DOE Order 5400.5, Office of Environment, Safety and Health, Washington, DC.

U.S. Department of Energy, 1996, Decontamination and Decommissioning Focus Area Results of the National Needs Assessment, U.S. Department of Energy-Office of Environmental Management, Washington, D.C.

U.S. Department of Energy, 1996, Decontamination and Decommissioning Focus Area Technology Summary, DOE/RL-93-0, U.S. Department of Energy-Office of Environmental Management, Washington, D.C.

U.S. Nuclear Regulatory Commission, 1982, Regulatory Guide, Termination of Operating Licenses for Nuclear Reactors, Regulatory Guide 1.86, Washington, D.C. 
Table 1.

Initial Screening for Pipe Decontamination

Technologies that have been eliminated from consideration

\begin{tabular}{|c|c|c|c|c|}
\hline \multirow[t]{2}{*}{ Technology Type } & \multicolumn{2}{|c|}{ Applicable Geometry } & \multirow[t]{2}{*}{ Description } & \multirow[t]{2}{*}{ Comments } \\
\hline & Internal & External & & \\
\hline $\begin{array}{l}\text { Ultra-High- } \\
\text { Pressure Water }\end{array}$ & $\mathrm{X}$ & $\mathrm{X}$ & $\begin{array}{l}\text { An internai combustion engine or } \\
\text { electric motor drives a pump that } \\
\text { generates up to } 60,000 \text { psig of water } \\
\text { pressure. The ultra-high-pressure pump } \\
\text { supplies water to a system of rotating } \\
\text { nozzles that sprays the water stream onto } \\
\text { the surface. The coating or substrate is } \\
\text { removed by the kinetic impact of the } \\
\text { water stream. The contamination and the } \\
\text { coating are flushed away from the } \\
\text { surface. Water systems can access and } \\
\text { flush convoluted surfaces. A standard } \\
\text { water supply is required to operate the } \\
\text { system. For the treatment of secondary } \\
\text { waste, a system is needed to collect and } \\
\text { separate the debris from the water. Both } \\
\text { would need to be treated. }\end{array}$ & $\begin{array}{l}\text { Based on the testing } \\
\text { performed by } \\
\text { HCET, the } \\
\text { technology fails to } \\
\text { meet the required } \\
\text { end point of a near- } \\
\text { white metal finish. }\end{array}$ \\
\hline $\begin{array}{l}\text { Carbon Dioxide } \\
\text { Blasting }\end{array}$ & & $\mathrm{X}$ & $\begin{array}{l}\text { This technology has a refrigerated liquid } \\
\mathrm{CO}_{2} \text { supply and a systern for converting } \\
\text { the liquid to a solid media that is used } \\
\text { for coating removal. Compressed liquid } \\
\text { is allowed to expand in a pressure- } \\
\text { controlled chamber in which the } \\
\text { temperature drops, causing a mixture of } \\
\mathrm{CO}_{2} \text { vapor and solid } \mathrm{CO}_{2} \text { snow to form. } \\
\text { The snow is collected, compressed, and } \\
\text { extruded through a die to produce pellets } \\
\text { of a selected size and hardness as needed } \\
\text { for decontamination. The } \mathrm{CO}_{2} \text { pellets } \\
\text { remove the coating and perform } \\
\text { decontamination by a combination of } \\
\text { impact, embrittlement, thermal } \\
\text { contraction, and gas expansion. The } \\
\text { frozen pellets provide thermal shock and } \\
\text { cause cracking. }\end{array}$ & $\begin{array}{l}\text { Based on the testing } \\
\text { performed by } \\
\text { HCET, the } \\
\text { technology fails to } \\
\text { meet the required } \\
\text { end point of a near- } \\
\text { white metal finish. }\end{array}$ \\
\hline
\end{tabular}


Table 1.

Initial Screening for Pipe Decontamination

Technologies that have been eliminated from consideration (Continued)

\begin{tabular}{|c|c|c|c|c|}
\hline \multirow[t]{2}{*}{ Technology Type } & \multicolumn{2}{|c|}{ Applicable Geometry } & \multirow[t]{2}{*}{ Description } & \multirow[t]{2}{*}{ Comments } \\
\hline & Internal & External & & \\
\hline Ice Blasting & & $X$ & $\begin{array}{l}\text { Compressed air carries the media to a } \\
\text { nozzle, which accelerates the media and } \\
\text { impinges the surface. The media scrape the } \\
\text { coating, rust. and contamination from the } \\
\text { surface. A vacuum system which } \\
\text { surrounds the nozzle removes the media } \\
\text { and the surface removed. The vacuum } \\
\text { system separates the usable media from the } \\
\text { remaining debris, and the media is reused } \\
\text { in the system. Compressed air or electricity } \\
\text { may power the vacuum system. Many } \\
\text { systems can operate a single nozzle or } \\
\text { multiple nozzles, increasing production } \\
\text { rates. Various grades and types of media } \\
\text { are available to customize the media to the } \\
\text { surface conditions. Media type and the } \\
\text { surface being removed can significantly } \\
\text { affect the amount of secondary waste to be } \\
\text { managed. }\end{array}$ & $\begin{array}{l}\text { Based on the testing } \\
\text { performed by } \\
\text { HCET, the } \\
\text { technology fails to } \\
\text { meet the required } \\
\text { end point of a near- } \\
\text { white metal finish. }\end{array}$ \\
\hline $\begin{array}{l}\text { Plastic Pellet } \\
\text { Blasting }\end{array}$ & & $\mathrm{X}$ & $\begin{array}{l}\text { This process uses compressed air or } \\
\text { centrifugal wheels to project plastic media } \\
\text { at the surface. The sharp-faceted particles } \\
\text { fracture on impact, leaving new sharp } \\
\text { edges to allow their continued use for } \\
\text { stripping. In general, the plastic media are } \\
\text { selected to be harder than the coating. In } \\
\text { typical applications, the air pressure } \\
\text { measures in the range from } 10 \text { to } 60 \text { psig. } \\
\text { Higher pressures remove coating faster but } \\
\text { also are more likely to induce substrate } \\
\text { damage. A vacuum system is used to } \\
\text { collect the media and removed surfaces. }\end{array}$ & $\begin{array}{l}\text { Based on the testing } \\
\text { performed by } \\
\text { HCET, the } \\
\text { technology fails to } \\
\text { meet the required } \\
\text { end point of a near- } \\
\text { white metal finish. }\end{array}$ \\
\hline $\begin{array}{l}\text { Automated } \\
\text { Brushing/ } \\
\text { Milling }\end{array}$ & $\mathrm{X}$ & $X$ & $\begin{array}{l}\text { This technique involves abrading the } \\
\text { targeted surface using course brushes or } \\
\text { media that are propelled against the } \\
\text { surface using centrifugal force. }\end{array}$ & $\begin{array}{l}\text { The technology fails } \\
\text { to meet the required } \\
\text { end point of a near- } \\
\text { white metal finish. }\end{array}$ \\
\hline $\begin{array}{l}\text { Chemical } \\
\text { Foams }\end{array}$ & $\mathrm{X}$ & $\mathrm{X}$ & $\begin{array}{l}\text { A series of aqueous chemical cleaning } \\
\text { solutions are applied to the surface for a } \\
\text { given period of time and then either } \\
\text { vacuumed or wiped off. The surfaces are } \\
\text { then rinsed off. Foam is reapplied if the } \\
\text { decontamination levels are not met. }\end{array}$ & $\begin{array}{l}\text { The technology fails } \\
\text { to meet the required } \\
\text { end point of a near- } \\
\text { white metal finish. }\end{array}$ \\
\hline
\end{tabular}


Table 1.

Initial Screening for Pipe Decontamination

Technologies that have been eliminated from consideration (Continued)

\begin{tabular}{|c|c|c|c|c|}
\hline \multirow[t]{2}{*}{ Technology Type } & \multicolumn{2}{|c|}{ Applicable Geometry } & \multirow[t]{2}{*}{ Description } & \multirow[t]{2}{*}{ Comments } \\
\hline & Internal & External & & \\
\hline Sponge Blasting & & $\mathrm{X}$ & $\begin{array}{l}\text { This technique consists of an open blasting } \\
\text { system with various grades of media. The } \\
\text { sponge media is made of a water-based } \\
\text { urethane matrix. During surface contact, } \\
\text { the media expands and contracts, exposing } \\
\text { the embedded abrasive and creating a } \\
\text { scrubbing effect. The sponge then recoils } \\
\text { and collapses around the contaminant, } \\
\text { trapping it. }\end{array}$ & $\begin{array}{l}\text { The technology fails } \\
\text { to meet the required } \\
\text { end point of a near- } \\
\text { white metal finish. }\end{array}$ \\
\hline Strippable Coating & $\mathrm{X}$ & $\mathrm{X}$ & $\begin{array}{l}\text { Strippable coatings involve the application } \\
\text { of a polymer mixture to a contaminated } \\
\text { surface. As the polymer reacts, the } \\
\text { contaminants are stabilized and become } \\
\text { entrained in the polymer. The } \\
\text { contaminated layer is pulled off, or it falls } \\
\text { off. }\end{array}$ & $\begin{array}{l}\text { The technology fails } \\
\text { to meet the required } \\
\text { end point of a near- } \\
\text { white metal finish. }\end{array}$ \\
\hline $\begin{array}{l}\text { Vibratory } \\
\text { Finishing }\end{array}$ & $\mathrm{X}$ & $\mathrm{X}$ & $\begin{array}{l}\text { Objects are placed in a basket filled with } \\
\text { abrasive media that are vibrated at a high } \\
\text { frequency in a cleaning solution. The } \\
\text { vibrating media produces a scouring action } \\
\text { that removes contamination. }\end{array}$ & $\begin{array}{l}\text { System is designed } \\
\text { for small parts. It is } \\
\text { not applicable to } \\
\text { large-bore pipe } \\
\text { decontamination. }\end{array}$ \\
\hline Soda Blasting & & $\mathrm{X}$ & $\begin{array}{l}\text { Compressed air advances the sodium } \\
\text { bicarbonate medium from a pressure pot to } \\
\text { a nozzle, where the medium combines for } \\
\text { stripping with a stream of water. The blast } \\
\text { medium and water mixture impacts the } \\
\text { surface, removing the coating and } \\
\text { contamination. The water helps control the } \\
\text { dust produced when the media impacts on } \\
\text { the coating and prohibits heat buildup. }\end{array}$ & $\begin{array}{l}\text { Based on the testing } \\
\text { performed by } \\
\text { HCET, the } \\
\text { technology fails to } \\
\text { meet the required } \\
\text { end point of a near- } \\
\text { white metal finish. }\end{array}$ \\
\hline Acid Etching & $\mathrm{X}$ & $\mathrm{X}$ & $\begin{array}{l}\text { This process uses a series of chemical } \\
\text { baths to etch and neutralize the coatings } \\
\text { and contamination on the surface. The } \\
\text { dwell time for the material depends on the } \\
\text { type of material, the type of contaminant, } \\
\text { and the method by which part became } \\
\text { contaminated. }\end{array}$ & $\begin{array}{l}\text { Process is not } \\
\text { designed to be a } \\
\text { mobile system. } \\
\text { Delete from } \\
\text { consideration. }\end{array}$ \\
\hline
\end{tabular}


Table 2.

Pipe Decontamination Technologies

\begin{tabular}{|c|c|c|c|c|}
\hline \multirow[t]{2}{*}{ Technology Type } & \multicolumn{2}{|c|}{ Applicable Geometry } & \multirow[t]{2}{*}{ Description } & \multirow[t]{2}{*}{ Comments } \\
\hline & Internal & External & & \\
\hline $\begin{array}{l}\text { Automated } \\
\text { Grinding }\end{array}$ & $\mathrm{X}$ & & $\begin{array}{l}\text { The system employs a series of cutting } \\
\text { stones which spin (using centrifugal force) } \\
\text { and hone the inside of the pipe. The } \\
\text { system spins at a speed that induces the } \\
\text { stones to be self-centering and to exhibit a } \\
\text { uniform force on the pipe interiors. }\end{array}$ & $\begin{array}{l}\text { Consider for further } \\
\text { review. A Flex-hone } \\
\text { system has been } \\
\text { developed and } \\
\text { tested to } \\
\text { decontaminate the } \\
\text { interior of piping } \\
\text { system. System is } \\
\text { able to achieve a } \\
\text { near-white metal } \\
\text { finish. }\end{array}$ \\
\hline Laser Ablation & $\mathrm{X}$ & $\mathrm{X}$ & $\begin{array}{l}\text { Laser systems have been employed to } \\
\text { perform paint removal from airplanes and } \\
\text { to remove graffiti. Systems are built to } \\
\text { specification. Work is currently underway } \\
\text { to develop systems for use in the } \\
\text { decontamination field. Laser light impacts } \\
\text { the surface causing the coating, rust, and } \\
\text { subsurface material to be abraded. }\end{array}$ & $\begin{array}{l}\text { Consider for further } \\
\text { review. System is } \\
\text { able to achieve a } \\
\text { near-white metal } \\
\text { finish. }\end{array}$ \\
\hline Flashlamp & & $\mathrm{X}$ & $\begin{array}{l}\text { The system works by pulsing an electric } \\
\text { current into a xenon gas filled quartz lamp, } \\
\text { producing an effect similar to a photo } \\
\text { camera flash. With the aid of a reflector } \\
\text { housed in the system's head, the emitted } \\
\text { light is concentrated and projected onto } \\
\text { coated surfaces. The intense light breaks } \\
\text { the chemical bond holding the material. } \\
\text { The resulting fine ash and gases are sucked } \\
\text { into a drum and fine scrubbed by a } \\
\text { vacuum. }\end{array}$ & $\begin{array}{l}\text { Consider for further } \\
\text { review. System may } \\
\text { be able to achieve a } \\
\text { near-white metal } \\
\text { finish. }\end{array}$ \\
\hline $\begin{array}{l}\text { Ultrasonic } \\
\text { Cleaning }\end{array}$ & $\mathrm{X}$ & $\mathrm{X}$ & $\begin{array}{l}\text { The contaminated component is placed in } \\
\text { a bath of cleaning solution. A vigorous } \\
\text { scrubbing action is produced by means of } \\
\text { ultrasonic vibration to clean the } \\
\text { component surfaces. }\end{array}$ & $\begin{array}{l}\text { Consider for further } \\
\text { review. System is } \\
\text { able to achieve a } \\
\text { near-white metal } \\
\text { finish. }\end{array}$ \\
\hline
\end{tabular}


Table 2.

Pipe Decontamination Technologies (Continued)

\begin{tabular}{|c|c|c|c|c|}
\hline \multirow[t]{2}{*}{ Technology Type } & \multicolumn{2}{|c|}{ Applicable Geometry } & \multirow[t]{2}{*}{ Description } & \multirow[t]{2}{*}{ Comments } \\
\hline & Internal & External & & \\
\hline Grit Blasting & $X$ & $X$ & $\begin{array}{l}\text { Compressed air carries the media to a } \\
\text { nozzle, which accelerates the media and } \\
\text { impinges the surface. The media scrapes the } \\
\text { coating, rust, and contamination from the } \\
\text { surface. A vacuum system that surrounds } \\
\text { the nozzle collects the media and removed } \\
\text { surface. The vacuum system separates the } \\
\text { usable media from the remaining debris, } \\
\text { and the media is reused in the system. The } \\
\text { system can operate a single nozzle or } \\
\text { multiple nozzles, increasing production } \\
\text { rates. Various grades and types of media are } \\
\text { available to customize the media to the } \\
\text { surface conditions. Media type and surface } \\
\text { being removed can significantly affect the } \\
\text { amount of secondary waste to be managed. }\end{array}$ & $\begin{array}{l}\text { Consider for further } \\
\text { review. System is } \\
\text { able to achieve a } \\
\text { near-white metal } \\
\text { finish. }\end{array}$ \\
\hline Shot Blasting & & $X$ & $\begin{array}{l}\text { The primary unit consists of a blast head } \\
\text { and a vacuum system. Hardened steel shot } \\
\text { is propelled at a high rate of speed from the } \\
\text { blast head to abrade the surface. The } \\
\text { materials removed and part of the steel shot } \\
\text { are collected by the vacuum system and } \\
\text { separated. The removed material is } \\
\text { collected in a drum, while the shot is } \\
\text { separated for recycling by the unit. The end } \\
\text { condition of the surface is determined by } \\
\text { the rate of speed of the machine and the } \\
\text { volume of shot fired into the blast chamber. }\end{array}$ & $\begin{array}{l}\text { Consider for further } \\
\text { review. System is } \\
\text { able to achieve a } \\
\text { near-white metal } \\
\text { finish. }\end{array}$ \\
\hline
\end{tabular}




\section{APPENDIX B}

\section{TECHNOLOGY SURVEY FOR DECONTAMINATION \\ OF INTERNAL AND EXTERNAL SURFACES OF PIPES}

\begin{tabular}{|l|l|l|}
\hline Vendor & Name & Science and Engineering Associates, Inc. \\
\hline Address & 6100 Uptown \\
\hline & Albuquerque, NM 87110 \\
\cline { 2 - 2 }
\end{tabular}

\begin{tabular}{|l|l|l|}
\hline Contact & Name & David Cremer \\
\hline & Phone & $(505) 884-2300$ \\
\cline { 2 - 3 } & Fax & $(505) 884-2991$ \\
\hline
\end{tabular}

\begin{tabular}{|l|l|l|}
\hline Technology & Name & Pipe Explorer \\
\hline & Description & \\
\cline { 2 - 3 } & Detector type & NaI, $\mathrm{C}_{\mathrm{s}} \mathrm{I}, \mathrm{ZnS}, \mathrm{BC}-408$ \\
\hline Spectrometric capabilities & \\
\hline Special features & \\
\hline Utilities required & \\
\hline
\end{tabular}

\begin{tabular}{|l|l|l|}
\hline Demonstration & Site & ANL, ITRI \\
\hline & Results & \\
\hline
\end{tabular}

\begin{tabular}{|l|l|l|}
\hline Applicable to pipe & External surface & No \\
\hline & Internal surface & Yes \\
\cline { 2 - 3 } & Length & 500 feet \\
\hline Diameter & $2 "$ to $40^{\prime \prime}$ \\
\hline
\end{tabular}

\begin{tabular}{|l|l|l|}
\hline Applicable to radiation & Alpha and detection range & $<6 \mathrm{dpm} / 100 \mathrm{~cm}^{2}$ \\
\hline & Beta and detection range & $<1000 \mathrm{dpm} / 100 \mathrm{~cm}^{2}$ \\
\cline { 2 - 3 } & Gamma and detection range & $<1000 \mathrm{dpm} / 100 \mathrm{~cm}^{2}$ \\
\hline
\end{tabular}

\begin{tabular}{|l|l|l|}
\hline Scan rate & Feet per minute & Depends on MDA- 0.1 to 30 \\
\hline
\end{tabular}

\begin{tabular}{|l|l|l|}
\hline Limitations related to & Contamination & None, Can measure all types \\
\hline & Pipe geometry & Calibration required for each geometry \\
\cline { 2 - 3 } & Pipe bends & Up to 8 \\
\hline & Other & Can circumvent $>50 \%$ obstruction. \\
\hline
\end{tabular}




\section{TECHNOLOGY SURVEY FOR DECONTAMINATION \\ OF INTERNAL AND EXTERNAL SURFACES OF PIPES}

\begin{tabular}{|c|c|c|}
\hline Vendor & Name & AIL Systems, Inc. \\
\hline & Address & 455 Commack Rd. \\
\hline & & Deer Park, NY 11729-4591 \\
\hline \multirow[t]{3}{*}{ Contact } & Name & Al Hennerborn \\
\hline & Phone & $(516) 595-6669$ \\
\hline & $\overline{\text { Fax }}$ & (516) 595-5582 \\
\hline \multirow[t]{6}{*}{ Technology } & Name & GammaCam $^{\text {Tht }}$ \\
\hline & Description & $\begin{array}{l}\text { Gamma Ray Imaging System - Portable instrument that } \\
\text { produces accurate 2-D images of gamma ray emitting } \\
\text { objects. The system provides real time pseudo-color } \\
\text { gamma ray imagery superimposed on a black and white } \\
\text { video picture to quickly locate and measure radiation } \\
\text { sources from a safe distance. System can operate in both } \\
\text { low and high background environments. }\end{array}$ \\
\hline & Detector type & High density terbium-activated scintillating glass \\
\hline & Spectrometric capabilities & $<80 \mathrm{keV}$ to $>1.3 \mathrm{MeV}$ \\
\hline & Special features & \\
\hline & Utilities required & \\
\hline \multirow[t]{4}{*}{ Demonstration } & Site & $\begin{array}{l}\text { Argonne National Lab, IL, D\&D Technology Demo at } \\
\text { CP-5 } 12 / 96\end{array}$ \\
\hline & Results & $\begin{array}{l}\text { Successfully imaged areas in reactor building during } \\
\text { D\&D Tech Demo }\end{array}$ \\
\hline & Site & Millstone Nuclear Power Plant, CT 7/97 \\
\hline & Results & Successfully imaged pipes containing gamma radiation \\
\hline \multirow[t]{4}{*}{ Applicable to pipe } & External surface & Yes \\
\hline & Internal surface & $\begin{array}{l}\text { Yes, system can locate internal gamma source in pipe by } \\
\text { imaging through pipe wall (obtaining image dependent } \\
\text { upon interior source strength and pipe wall thickness). }\end{array}$ \\
\hline & Length & $\begin{array}{l}\text { Dependent upon external distance of sensor head to pipe } \\
\left(\text { FOV }=50^{\circ}\right)\end{array}$ \\
\hline & Diameter & $\begin{array}{l}\text { Dependent upon external distance of sensor head to pipe } \\
\left(\text { FOV }=50^{\circ}\right)\end{array}$ \\
\hline \multirow[t]{3}{*}{ Applicable to radiation } & Alpha and detection range & Cannot detect \\
\hline & Beta and detection range & Cannot detect \\
\hline & Gamma and detection range & $\begin{array}{l}\text { Sensor head requires } 1-2 \mathrm{mR} \text { integrated dose in low } \\
\text { background environments }\end{array}$ \\
\hline
\end{tabular}




\begin{tabular}{|l|l|l|}
\hline Scan rate & Feet per minute & $\begin{array}{l}\text { N/A. System captures a still image of scene. Sensor head } \\
\text { requires repositioning to capture another area image. }\end{array}$ \\
\hline Limitations related to & Contamination & $\begin{array}{l}\text { Sealed enclosure required for operation in air } \\
\text { contaminated areas }\end{array}$ \\
\hline & Pipe geometry & No \\
\cline { 2 - 3 } & Pipe bends & $\begin{array}{l}\text { No } \\
\text { Other } \\
\text { has operated in was 70 R/hr. The GammaCam }{ }^{\text {TM }} \text { will not } \\
\text { meet DOE surface-release criteria for alpha and beta } \\
\text { radiations. }\end{array}$ \\
\hline
\end{tabular}


TECHNOLOGY SURVEY FOR DECONTAMINATION

OF INTERNAL AND EXTERNAL SURFACES OF PIPES

\begin{tabular}{|l|l|l|}
\hline Vendor & Name & Quantrad Sensor, Inc. \\
\hline \multirow{2}{*}{ Address } & 2360 Owen Street \\
\cline { 2 - 2 } & Santa Clara, CA 95054 \\
\cline { 2 - 2 }
\end{tabular}

\begin{tabular}{|l|l|l|}
\hline Contact & Name & Ed Browning \\
\hline & Phone & $(408) 727-7826$ or $(408) 727-7827$ \\
\hline Fax & $(408) 727-7828$ \\
\hline
\end{tabular}

\begin{tabular}{|l|l|l|}
\hline Technology & Name & Scout MCA \\
\hline & Description & Portable Multichannel Analyser \\
\hline Detector type & Various sensor types \\
\hline Spectrometric capabilities & Alpha, Beta, Gamma, Neutrons \\
\hline Special features & \\
\hline Utilities required & \\
\hline
\end{tabular}

\begin{tabular}{|l|l|l|}
\hline Demonstration & Site & \\
\hline Results & \\
\hline
\end{tabular}

\begin{tabular}{|l|l|l|}
\hline Applicable to pipe & External surface & Yes \\
\hline & Internal surface & Most \\
\hline & Length & Any \\
\cline { 2 - 3 } & $>=1 / 2^{\prime \prime}$ \\
\hline
\end{tabular}

\begin{tabular}{|l|l|l|}
\hline Applicable to radiation & Alpha and detection range & up to $10 \mathrm{MeV}$ \\
\hline & Beta and detection range & up to $500 \mathrm{keV}$ \\
\hline Gamma and detection range & $30 \mathrm{keV}$ to $2.5 \mathrm{MeV}$ \\
\hline
\end{tabular}

\begin{tabular}{|l|l|l|}
\hline Scan rate & Feet per minute & Any \\
\hline
\end{tabular}

\begin{tabular}{|l|l|l|}
\hline Limitations related to & Contamination & No problems/cleanable surface \\
\hline & Pipe geometry & Any \\
\hline & Pipe bends & 3" x 1/2" gamma sensors \\
\hline Other & \\
\hline
\end{tabular}




\section{TECHNOLOGY SURVEY FOR DECONTAMINATION}

OF INTERNAL AND EXTERNAL SURFACES OF PIPES

\begin{tabular}{|l|l|l|}
\hline Vendor & Name & Ordela, Inc. \\
\hline & Address & 1009 Alvin Weinberg Dr. \\
Oak Ridge, TN 37830
\end{tabular}

\begin{tabular}{|l|l|l|}
\hline Contact & Name & Wayne Graves / Danny Kopp \\
\hline & Phone & $(423) 483-8675$ \\
\hline Fax & $(423) 483-8404$ \\
\hline
\end{tabular}

\begin{tabular}{|l|l|l|}
\hline Technology & Name & Bore-Hole Frisch-Grid \\
\hline & Description & $\begin{array}{l}\text { Large-area, ionization chamber for rapid alpha } \\
\text { spectometry }\end{array}$ \\
\cline { 2 - 3 } & Detector type & Gridded Ionization Chamber \\
\cline { 2 - 3 } & Spectrometric capabilities & Yes, resolution $<60 \mathrm{keV}$ FWHM at 5 MeV alpha energy \\
\cline { 2 - 3 } & $\begin{array}{l}\text { Special features } \\
\text { efficiensitive to beta and gamma radiation, alpha counting } \\
\text { wall }\end{array}$ \\
\hline Utilities required & $\begin{array}{l}\text { A source of Ar-CH4 } \text { (P-10) gas at }<200 \mathrm{kPa} \text { absolute } \\
\text { pressure }\end{array}$ \\
\hline Demonstration & Site & LITCO \\
\hline
\end{tabular}

\begin{tabular}{|l|l|l|}
\hline Applicable to pipe & External surface & N/A \\
\hline & Internal surface & Yes \\
\hline Length & Any \\
\cline { 2 - 3 } & Diameter & $>=6 "$ \\
\hline
\end{tabular}

\begin{tabular}{|l|l|l|}
\hline Applicable to radiation & Alpha and detection range & Yes, $<60 \mathrm{keV}$ FWHM for alpha \\
\hline & Beta and detection range & No \\
\cline { 2 - 3 } & Gamma and detection range & No \\
\cline { 2 - 3 }
\end{tabular}

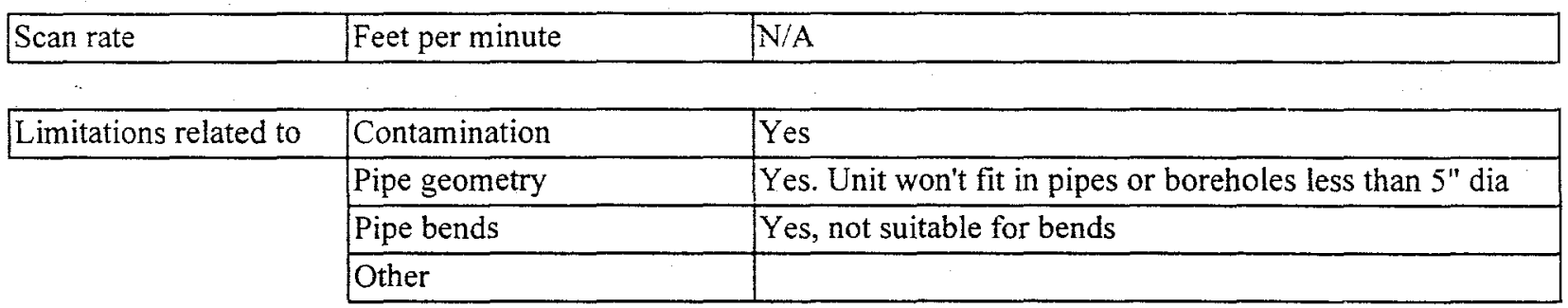




\section{TECHNOLOGY SURVEY FOR DECONTAMINATION OF INTERNAL AND EXTERNAL SURFACES OF PIPES}

\begin{tabular}{|l|l|l|}
\hline Vendor & Name & Los Alamos National Laboratory \\
\hline & Address & MS J561, Group NIS-6 \\
\cline { 2 - 3 } & Los Alamos, NM 87545 \\
\hline
\end{tabular}

\begin{tabular}{|l|l|l|}
\hline Contact & Name & Jim Koster \\
\hline & Phone & $(505) 667-3346$ \\
\cline { 2 - 3 } & Fax & $(505) 665-9277$ \\
\hline
\end{tabular}

\begin{tabular}{|l|l|l|}
\hline Technology & Name & Long Range Alpha Detection \\
\hline & Description & Pipe Monitor \\
\hline Detector type & LRAD \\
\cline { 2 - 3 } & Spectrometric capabilities & None, measures gross Ionization only \\
\cline { 2 - 3 } & Special features & Flowing air to transfer ions to the sensitive volume \\
\hline
\end{tabular}

\begin{tabular}{|l|l|l|}
\hline Demonstration & Site & LANL \\
\hline & Results & Good, detects $200 \mathrm{dpm}$ or more \\
\cline { 2 - 3 }
\end{tabular}

\begin{tabular}{|l|l|l|}
\hline Applicable to pipe & External surface & Any \\
\hline & Internal surface & Any \\
\cline { 2 - 3 } & Length & Any \\
\cline { 2 - 3 } & Diameter & Any \\
\hline
\end{tabular}

\begin{tabular}{|l|l|l|}
\hline Applicable to radiation & Alpha and detection range & High sensitivity, whole pipe \\
\hline & Beta and detection range & Low sensitivity \\
\cline { 2 - 3 } & Gamma and detection range & Very low sensitivity \\
\hline
\end{tabular}

\begin{tabular}{|l|l|l|}
\hline Scan rate & Feet per minute & Whole pipe/2 $\mathrm{min}$. \\
\hline
\end{tabular}

\begin{tabular}{|l|l|l|}
\hline Limitations related to & Contamination & Not very good for beta and gamma detection \\
\hline & Pipe geometry & Must allow air flow through pipe \\
\hline Pipe bends & Not a problem \\
\hline Other & \\
\hline
\end{tabular}




\section{TECHNOLOGY SURVEY FOR DECONTAMINATION OF INTERNAL AND EXTERNAL SURFACES OF PIPES}

\begin{tabular}{|l|l|l|}
\hline Vendor & Name & INEL/DTD Robotics \\
\hline & Address & P.O. Box 1625 \\
\cline { 2 - 3 } & & Idaho Falls, ID 83415-2220 \\
\hline
\end{tabular}

\begin{tabular}{|l|l|l|}
\hline Contact & Name & David Willis \\
\hline & Phone & $(208) 526-8613$ \\
\hline & Fax & $(208) 526-7688$ \\
\hline
\end{tabular}

\begin{tabular}{|l|l|l|}
\hline Technology & Name & Small Pipe Characterization System \\
\hline & Description & internal pipe crawler \\
\cline { 2 - 3 } & Detector type & Marlin - Gerin \\
\hline Spectrometric capabilities & Never tested \\
\hline Special features & The computer controlled crawier moves inside the pipe \\
\hline Utilities required & \\
\hline
\end{tabular}

\begin{tabular}{|l|l|l|}
\hline Demonstration & Site & No work for demonstrations \\
\hline & Results & Performed using radiation detector \\
\cline { 2 - 3 }
\end{tabular}

\begin{tabular}{|l|l|l|}
\hline Applicable to pipe & External surface & No \\
\hline & Internal surface & Yes \\
\cline { 2 - 3 } & Length & Approximately 15 feet \\
\hline & Diameter & 2 to 3 inches \\
\hline
\end{tabular}

\begin{tabular}{|l|l|l|}
\hline Applicable to radiation & Alpha and detection range & N/A \\
\hline & Beta and detection range & Unknown \\
\cline { 2 - 3 } & Gamma and detection range & Unknown \\
\hline
\end{tabular}

\begin{tabular}{|l|l|l|}
\hline Scan rate & Feet per minute & Unknown \\
\hline
\end{tabular}

\begin{tabular}{|l|l|l|}
\hline Limitations related to & Contamination & Yes \\
\hline & Pipe geometry & System never field for radiation measurement \\
\cline { 2 - 3 } & Pipe bends & Not designed for bends \\
\cline { 2 - 3 } & Other & \\
\hline
\end{tabular}




\section{TECHNOLOGY SURVEY FOR DECONTAMINATION \\ OF INTERNAL AND EXTERNAL SURFACES OF PIPES}

\begin{tabular}{|l|l|l|}
\hline Vendor & Name & Canberra Industries \\
\hline & Address & 800 Research Parkway \\
\hline & Meriden CT, 06457 \\
\hline
\end{tabular}

\begin{tabular}{|l|l|l|}
\hline Contact & Name & Frazier Bronson \\
\hline & Phone & $(203) 639-2345$ \\
\cline { 2 - 3 } & Fax & $(203) 235-1347$ \\
\hline
\end{tabular}

\begin{tabular}{|l|l|l|}
\hline Technology & ISOCS (In-Situ Object Counting System) \\
\hline & Description & $\begin{array}{l}\text { Integrated system to do quantitative nuclide-specific assay } \\
\text { of many different types of objects, including pipes. } \\
\text { Product includes mathematical calibration software for } \\
\text { field calibration of nearly all pipe sizes and source } \\
\text { distribution geometries }\end{array}$ \\
\cline { 2 - 3 } & Detector type & High resolution Germanium \\
\hline Spectrometric capabilities & Yes \\
\hline Special features & $\begin{array}{l}\text { Activity for each individual nuclide is determined, without } \\
\text { significant interference from other nuclides present in the } \\
\text { sample or in the background, also useful for drums, boxes, } \\
\text { walls, floors, ceilings, etc. }\end{array}$ \\
\hline Utilities required & \\
\hline
\end{tabular}

\begin{tabular}{|l|l|l|}
\hline Demonstration & Site & $\begin{array}{l}\text { USDOE, US Nuclear Power Plant, US Research Institute, } \\
\text { German Decommissioning Project, German Regulatory } \\
\text { Agency }\end{array}$ \\
\hline & Results & Very good \\
\hline
\end{tabular}

\begin{tabular}{|l|l|l|}
\hline Applicable to pipe & External surface & Not as standard, but can be done as special \\
\hline Internal surface & $\begin{array}{l}\text { Yes. Applicable to various thickness and composition. } \\
\text { Also includes uniform radial distribution, and/or bottom } \\
\text { distribution. }\end{array}$ \\
\cline { 2 - 3 } & Uength & Up to 100 meters \\
\hline Diameter & Ueters \\
\hline
\end{tabular}

\begin{tabular}{|l|l|l|}
\hline Applicable to radiation & Alpha and detection range & $\begin{array}{l}\text { Detection via X-ray and/or gamma decay chain (most } \\
\text { alpha emitters also emit photons) }\end{array}$ \\
\hline Beta and detection range & $\begin{array}{l}\text { Detection via X-ray and/or gamma decay chain } \\
\text { accompanying a beta decay }\end{array}$ \\
\hline
\end{tabular}


Gamma and detection range Depends on detector separation, and counting time, suitable for free release for most nuclides

\begin{tabular}{|l|l|l|}
\hline Scan rate & Feet per minute & $5^{\prime}$ to $10^{\prime}$ in $5-15$ minutes \\
\hline Limitations related to & Contamination & Can be protected using a plastic cover \\
\hline & Pipe geometry & $\begin{array}{l}\text { Straight cylindrical shapes (Rectangular or curved shapes } \\
\text { as special), diameter depends on detector assembly }\end{array}$ \\
\cline { 2 - 3 } & Pipe bends & Not standard, but as special geometry \\
\cline { 2 - 3 } & Other & \\
\cline { 2 - 3 }
\end{tabular}


TECHNOLOGY SURVEY FOR DECONTAMINATION

OF INTERNAL AND EXTERNAL SURF ACES OF PIPES

\begin{tabular}{|l|l|l|}
\hline Vendor & Name & Eberline Instruments \\
\hline & Address & P.O. Box 2108 \\
\cline { 2 - 3 } & Santa Fe, NM 87504 \\
\hline
\end{tabular}

\begin{tabular}{|l|l|l|}
\hline Contact & Name & Jeff Sawyer \\
\hline & Phone & $(505) 471-3232$ ext: 237 \\
\cline { 2 - 3 } & Fax & $(505) 475-9221$ \\
\hline
\end{tabular}

\begin{tabular}{|l|l|l|}
\hline Technology & Name & IPM \\
\hline & Description & Internal Pipe Monitor \\
\hline & Detector type & Gas Flow Proportional \\
\hline Spectrometric capabilities & None \\
\hline & Special features & \\
\cline { 2 - 3 } & Utilities required & \\
\hline
\end{tabular}

\begin{tabular}{|l|l|l|}
\hline Demonstration & Site & None \\
\hline & Results & \\
\hline
\end{tabular}

\begin{tabular}{|l|l|l|}
\hline Applicable to pipe & External surface & No, different system \\
\hline & Internal surface & Yes \\
\cline { 2 - 3 } & Length & $<10$ meters \\
\hline & Diameter & Various detectors available \\
\hline
\end{tabular}

\begin{tabular}{|l|l|l|}
\hline Applicable to radiation & Alpha and detection range & Yes, dependent of count times \\
\hline & Beta and detection range & Yes, dependent of count times \\
\hline Gamma and detection range & Yes, dependent of count times \\
\hline
\end{tabular}

\begin{tabular}{|l|l|l|}
\hline Scan rate & Feet per minute & Manual system \\
\hline
\end{tabular}

\begin{tabular}{|l|l|l|}
\hline Limitations related to & Contamination & Yes \\
\hline & Pipe geometry & Right cylinder detector \\
\cline { 2 - 3 } & Pipe bends & Straight pipe only \\
\cline { 2 - 3 } & Other & Well known detector technology \\
\hline
\end{tabular}


TECHNOLOGY SURVEY FOR DECONTAMINATION

OF INTERNAL AND EXTERNAL SURFACES OF PIPES

\begin{tabular}{|l|l|l|}
\hline Vendor & Name & BNFL Instruments, Limited \\
\hline & Address & Pelham House \\
\hline & Calderbridge, Cumbria CA20 IDB, LK \\
\cline { 2 - 3 }
\end{tabular}

\begin{tabular}{|l|l|l|}
\hline Contact & Name & Paul Read / Norman Gardner \\
\hline & Phone & $44-19467-85015 / 85036$ \\
\cline { 2 - 3 } & Fax & $44-19467-85019 / 85001$ \\
\hline
\end{tabular}

\begin{tabular}{|l|l|l|}
\hline Technology & Name & IonSens \\
\hline & Description & Detect ionization in air from aipha emission \\
\cline { 2 - 3 } & Detector type & Parallel plate electrometer \\
\cline { 2 - 3 } & Spectrometric capabilities & None, measures gross Ionization only \\
\cline { 2 - 3 } & Special features & Based on measurement of ions produced by alpha radiation \\
\hline & Utilities required & Flowing air to transfer ions to the sensitive volume \\
\hline
\end{tabular}

\begin{tabular}{|l|l|l|}
\hline Demonstration & Site & BNFL, Sellafield, Seascale, Cumbria CA20 1PG \\
\hline & Results & Detection limit few tens of bequerels \\
\cline { 2 - 3 }
\end{tabular}

\begin{tabular}{|l|l|l|}
\hline Applicable to pipe & External surface & Yes \\
\hline & Internal surface & Yes \\
\cline { 2 - 3 } & Length & 20 feet \\
\cline { 2 - 3 } & Diameter & $6 "$ (development to maximum 24" dia in hand) \\
\cline { 2 - 3 }
\end{tabular}

\begin{tabular}{|l|l|l|}
\hline Applicable to radiation & Alpha and detection range & Yes \\
\hline & Beta and detection range & No \\
\cline { 2 - 3 } & Gamma and detection range & No \\
\hline
\end{tabular}

\begin{tabular}{|l|l|l|}
\hline Scan rate & Feet per minute & For 20 feet long, 6 inch dia, 3 minutes \\
\hline
\end{tabular}

\begin{tabular}{|l|l|l|}
\hline Limitations related to & Contamination & $\begin{array}{l}\text { Loose contamination can lead to detector contamination } \\
\text { requiring subsequent cleaning }\end{array}$ \\
\hline & Pipe geometry & No \\
\hline Pipe bends & No \\
\hline Other & \\
\hline
\end{tabular}




\section{TECHNOLOGY SURVEY FOR DECONTAMINATION OF INTERNAL AND EXTERNAL SURFACES OF PIPES}

\begin{tabular}{|l|l|l|}
\hline Vendor & Name & Scientific Ecology Group, Inc. \\
\hline & Address & 1560 Bear Creek Road \\
\hline \multirow{5}{*}{} & P.O. Box. 230 \\
\cline { 2 - 3 } & Oak Ridge, TN 37830 \\
\cline { 2 - 2 }
\end{tabular}

\begin{tabular}{|l|l|l|}
\hline Contact & Name & Don Neely \\
\hline & Phone & $(423) 376-8237$ \\
\cline { 2 - 3 } & Fax & $(423) 376-8297$ \\
\hline
\end{tabular}

\begin{tabular}{|l|l|l|}
\hline Technology & Name & Large Diameter Pipe Survey Rig \\
\hline & Description & $\begin{array}{l}\text { Expandable rig with 1-4 attached gas flow proportional } \\
\text { detectors for surveying 10" to 24" diameter piping or } \\
\text { cylinders }\end{array}$ \\
\hline & Gas Flow Proportional \\
\hline Spectrometric capabilities & Total alpha, beta-gamma \\
\hline Special features & \\
\hline Utilities required & \\
\hline
\end{tabular}

\begin{tabular}{|l|l|l|}
\hline Demenstration & Site & Fort St. Vrain Nuclear Facility Decommissioning \\
\hline & Results & $\begin{array}{l}\text { Performed characterization and final surveys of } \\
\text { equipment storage wells and large gas cylinders }\end{array}$ \\
\hline
\end{tabular}

\begin{tabular}{|l|l|l|}
\hline Applicable to pipe & External surface & No \\
\hline \multirow{2}{*}{} & Internal surface & Yes \\
\hline & Length & Up to $12^{\prime}$ \\
\hline & Diameter & $10^{\prime \prime}$ to $24^{\prime \prime}$ \\
\hline
\end{tabular}

\begin{tabular}{|l|l|l|}
\hline Applicable to radiation & Alpha and detection range & $\begin{array}{l}500 \text { to } 1,000,000 \mathrm{dpm} / 100 \mathrm{~cm}^{2} \text { (scanning mode), } \\
100 \text { to } 1,000,000 \mathrm{dpm} / 100 \mathrm{~cm}^{2} \text { (fixed-measurement mode) }\end{array}$ \\
\hline \multirow{2}{*}{$\begin{array}{l}\text { Beta and detection range } \\
2,500 \text { to } 1,000,000 \mathrm{dpm} / 100 \mathrm{~cm}^{2} \text { (scanning mode) } \\
500 \text { to } 1,000,000 \mathrm{dpm} / 100 \mathrm{~cm}^{2} \text { (fixed-measurement mode) }\end{array}$} \\
\cline { 2 - 3 } & Gamma and detection range & Responds to gamma, but not calibrated for quantification \\
\hline
\end{tabular}

\begin{tabular}{|l|l|l|}
\hline Scan rate & Feet per minute & 10 feet/min. \\
\hline Limitations related to & Contamination & Yes \\
\hline & Pipe geometry & Straight pipe 10" to 24" in diameter \\
\cline { 2 - 3 } & Pipe bends & No \\
\cline { 2 - 3 } & Other & $\begin{array}{l}\text { Hand operated with attached pole, useful for beta energies } \\
>50 \mathrm{keV}\end{array}$ \\
\hline
\end{tabular}

TECHNOLOGY SURVEY FOR DECONTAMINATION 
OF INTERNAL AND EXTERNAL SURFACES OF PIPES

\begin{tabular}{|l|l|l|}
\hline Vendor & Name & Scientific Ecology Group, Inc. \\
\hline & Address & 1560 Bear Creek Road \\
\hline & P.O. Box. 230 \\
\cline { 2 - 3 } & Oak Ridge, TN 37830 \\
\hline
\end{tabular}

\begin{tabular}{|l|l|l|}
\hline Contact & Name & Don Neely \\
\hline & Phone & $(423) 376-8237$ \\
\hline Fax & $(423) 376-8297$ \\
\hline
\end{tabular}

\begin{tabular}{|l|l|l|}
\hline Technology & Name & SP-175-3M \\
\hline Description & $\begin{array}{l}\text { Expandable (motor-controlled) survey assembly consisting } \\
\text { of three } 1.75 " \text { diameter GM detectors. Assembly detection } \\
\text { area } 46.5 \mathrm{~cm}^{2}\end{array}$ \\
\cline { 2 - 3 } & Geiger Muller (GM) \\
\hline Spectrom type & Total alpha and beta-gamma \\
\hline Special features & \\
\hline Utilities required & \\
\hline
\end{tabular}

\begin{tabular}{|l|l|l|}
\hline Demonstration & Site & Fort St. Vrain Nuclear Facility Decommissioning \\
\hline Results & $\begin{array}{l}\text { Performed characterization and firal surveys of plant } \\
\text { system piping from 5" to 12" diameter }\end{array}$ \\
\hline
\end{tabular}

\begin{tabular}{|l|l|l|}
\hline Applicable to pipe & External surface & No \\
\hline Internal surface & Yes \\
\hline Length & Up to 12 feet \\
\hline Diameter & 5 to 12 inches \\
\hline
\end{tabular}

\begin{tabular}{|l|l|l|}
\hline Applicable to radiation & Alpha and detection range & $\begin{array}{l}3,000 \text { to } 1,000,000 \mathrm{dpm} / 100 \mathrm{~cm}^{2} \text { (scanning mode), } \\
1,000 \text { to } 1,000,000 \mathrm{dpm} / 100 \mathrm{~cm}^{2} \text { (fixed-mieasurement } \\
\text { mode) }\end{array}$ \\
\hline Beta and detection range & $\begin{array}{l}3,000 \text { to } 1,000,000 \mathrm{dpm} / 100 \mathrm{~cm}^{2} \text { (scanning mode), } \\
1,000 \text { to } 1,000,000 \mathrm{dpm} / 100 \mathrm{~cm}^{2} \text { (fixed-measurement } \\
\text { mode) }\end{array}$ \\
\cline { 2 - 3 } & Gamma and detection range & Responds to gamma, but not calibrated for quantification \\
\hline
\end{tabular}

\begin{tabular}{|c|c|c|}
\hline Scan rate & Feet per minute & 5 \\
\hline \multirow[t]{4}{*}{ Limitations related to } & Contamination & Yes \\
\hline & Pipe geometry & Straight pipe 5 " to 12 " diameter \\
\hline & Pipe bends & No \\
\hline & Other & $\begin{array}{l}\text { Useful for beta energies }>50 \mathrm{keV} \text {, hand operated with } \\
\text { attached pole }\end{array}$ \\
\hline
\end{tabular}


TECHNOLOGY SURVEY FOR DECONTAMINATION

OF INTERNAL AND EXTERNAL SURFACES OF PIPES

\begin{tabular}{|l|l|l|}
\hline Vendor & Name & Scientific Ecology Group, Inc. \\
\hline \multirow{2}{*}{ Address } & 1560 Bear Creek Road \\
\hline & P.O. Box. 230 \\
\cline { 2 - 3 } & Oak Ridge, TN 37830 \\
\cline { 2 - 2 }
\end{tabular}

\begin{tabular}{|l|l|l|}
\hline Contact & Name & Don Neely \\
\hline \multirow{y}{*}{ Fax } & $(423) 376-8237$ \\
\hline
\end{tabular}

\begin{tabular}{|l|l|l|}
\hline Technology & Name & SP-113-3M \\
\hline & Description & $\begin{array}{l}\text { Expandable (motor controller) survey assembly consisting } \\
\text { of three } 1.13 \text { " diameter GM detectors. Assembly detection } \\
\text { area } 19.4 \mathrm{~cm}^{2}\end{array}$ \\
\cline { 2 - 3 } & Geiger Muller (GM) \\
\cline { 2 - 3 } & Setector type & \\
\cline { 2 - 3 } & Spectrometric capabilities & Total alpha and beta \\
\hline & Utilities required & \\
\hline
\end{tabular}

\begin{tabular}{|l|l|l|}
\hline Demonstration & Site & Fort St. Vrain Nuclear Facility Decommissioning \\
\hline & Results & $\begin{array}{l}\text { Performed characterization and final surveys of plant } \\
\text { system piping from 4" to 6" diameter }\end{array}$ \\
\hline
\end{tabular}

\begin{tabular}{|l|l|l|}
\hline Applicable to pipe & External surface & No \\
\hline & Internal surface & Yes \\
\cline { 2 - 3 } & Length & Up to 12 feet \\
\cline { 2 - 3 } & Diameter & 4 to 6 inches \\
\hline
\end{tabular}

\begin{tabular}{|l|l|l|}
\hline Applicable to radiation & Alpha and detection range & $\begin{array}{l}5,000 \text { to } 1,000,000 \mathrm{dpm} / 100 \mathrm{~cm}^{2} \text { (scanning mode), } \\
1,000 \text { to } 1,000,000 \mathrm{dpm} / 100 \mathrm{~cm}^{2} \text { (fixed-measurement } \\
\text { mode) }\end{array}$ \\
\hline & Beta and detection range & $\begin{array}{l}5,000 \text { to } 1,000,000 \mathrm{dpm} / 100 \mathrm{~cm}^{2} \text { (scanning mode), } \\
1,000 \text { to } 1,000,000 \mathrm{dpm} / 100 \mathrm{~cm}^{2} \text { (fixed-measurement } \\
\text { mode) }\end{array}$ \\
\hline Gamma and detection range & Responds to gamma, but not calibrated for quantification \\
\hline
\end{tabular}

\begin{tabular}{|c|c|c|}
\hline Scan rate & Feet per minute & 5 \\
\hline \multirow[t]{4}{*}{ Limitations related to } & Contamination & Yes \\
\hline & Pipe geometry & Straight pipe $4^{\prime \prime}$ to 6 " diameter. \\
\hline & Pipe bends & No \\
\hline & Other & $\begin{array}{l}\text { Useful for beta energies }>50 \mathrm{keV} \text {, hand operated with } \\
\text { attached pole. }\end{array}$ \\
\hline
\end{tabular}


TECHNOLOGY SURVEY FOR DECONTAMINATION

OF INTERNAL AND EXTERNAL SURFACES OF PIPES

\begin{tabular}{|l|l|l|}
\hline Vendor & Name & Scientific Ecology Group, Inc. \\
\hline & Address & 1560 Bear Creek Road \\
\hline & & P.O. Box. 230 \\
\cline { 2 - 3 } & Oak Ridge, TN 37830 \\
\hline & & \\
\hline Contact & Name & Don Neely \\
\hline & Phone & $(423) 376-8237$ \\
\hline & Fax & $(423) 376-8297$ \\
\hline
\end{tabular}

\begin{tabular}{|l|l|l|}
\hline Technology & Name & SP-113-3T \\
\hline & Description & $\begin{array}{l}\text { Expandable (motor controller) survey assembly consisting } \\
\text { of three } 1.13 \text { "diameter GM detectors. Assembly detection } \\
\text { area } 19.4 \mathrm{~cm}^{2}\end{array}$ \\
\hline & Geiger Muller (GM). \\
\hline Detector type & Total alpha and beta-gamma \\
\hline Spectrometric capabilities & \\
\hline Special features & \\
\hline Utilities required & \\
\hline
\end{tabular}

\begin{tabular}{|l|l|l|}
\hline Demonstration & Site & Fort St. Vrain Nuclear Facility Decommissioning \\
\hline Results & $\begin{array}{l}\text { Performed characterization and final survey of plant system } \\
\text { piping (including piping with bends) from 4" to 6" diameter }\end{array}$ \\
\hline
\end{tabular}

\begin{tabular}{|l|l|l|}
\hline Applicable to pipe & External surface & No \\
\hline & Internal surface & Yes \\
\hline Length & Up to 50 feet \\
\hline Diameter & 4 to 6 inches \\
\hline
\end{tabular}

\begin{tabular}{|l|l|l|}
\hline Applicable to radiation & Alpha and detection range & $\begin{array}{l}5,000 \text { to } 1,000,000 \mathrm{dpm} / 100 \mathrm{~cm}^{2} \text { (scanning mode), } \\
1,000 \text { to } 1,000,000 \mathrm{dpm} / 100 \mathrm{~cm}^{2} \text { (fixed-measurement } \\
\text { mode) }\end{array}$ \\
\hline Beta and detection range & $\begin{array}{l}5,000 \text { to } 1,000,000 \mathrm{dpm} / 100 \mathrm{~cm}^{2} \text { (scanning mode), } \\
1,000 \text { to } 1,000,000 \mathrm{dpm} / 100 \mathrm{~cm}^{2} \text { (fixed-measurement } \\
\text { mode) }\end{array}$ \\
\cline { 2 - 3 } & Gamma and detection range & Responds to gamma but not calibrated for quantification \\
\hline
\end{tabular}

\begin{tabular}{|c|c|c|}
\hline Scan rate & Feet per minute & 5 \\
\hline \multirow[t]{4}{*}{ Limitations related to } & Contamination & Yes \\
\hline & Pipe geometry & 4" to 6" diameter piping (including piping with bends) \\
\hline & Pipe bends & Yes \\
\hline & Other & $\begin{array}{l}\text { Pulled through piping with attached cables, useful for beta } \\
\text { energies }>50 \mathrm{keV}\end{array}$ \\
\hline
\end{tabular}


TECHNOLOGY SURVEY FOR DECONTAMINATION

OF INTERNAL AND EXTERNAL SURFACES OF PIPES

\begin{tabular}{|l|l|l|}
\hline Vendor & Name & Scientific Ecology Group, Inc. \\
\hline \multirow{2}{*}{ Address } & 1560 Bear Creek Road \\
\hline & P.O. Box. 230 \\
\cline { 2 - 3 } & Oak Ridge, TN 37830 \\
\hline
\end{tabular}

\begin{tabular}{|l|l|l|}
\hline Contact & Name & Don Neely \\
\hline & Phone & $(423) 376-8237$ \\
\hline & Fax & $(423) 376-8297$ \\
\hline
\end{tabular}

\begin{tabular}{|l|l|l|}
\hline Technology & Name & SN-113-3C \\
\hline & Description & $\begin{array}{l}\text { Flexible detector assembly consisting of three 1.13" } \\
\text { diameter GM detectors attached to wheeled carriers. } \\
\text { Assembly detection area } 19.4 \mathrm{~cm}^{2}\end{array}$ \\
\cline { 2 - 3 } & Geiger Muller (GM) \\
\cline { 2 - 3 } & Spectrometric capabilities & Total alpha and beta-gamma \\
\hline & Special features & \\
\hline Utilities required & \\
\hline
\end{tabular}

\begin{tabular}{|l|l|l|}
\hline Demonstration & Site & Fort St. Vrain Nuclear Facility Decommissioning \\
\hline Results & $\begin{array}{l}\text { Performed characterization and final surveys of plant } \\
\text { system (including piping with bends) from 2" to 3" } \\
\text { diameter }\end{array}$ \\
\hline
\end{tabular}

\begin{tabular}{|l|l|l|}
\hline Applicable to pipe & External surface & No \\
\hline & Internal surface & yes \\
\hline & Length & Up to 50 feet \\
\hline Diameter & 2 to 3 inches \\
\hline
\end{tabular}

\begin{tabular}{|l|l|l|}
\hline Applicable to radiation & Alpha and detection range & $\begin{array}{l}5,000 \text { to } 1,000,000 \mathrm{dpm} / 100 \mathrm{~cm}^{2} \text { (scanning mode) } \\
1,000 \text { to } 1,000,000 \mathrm{dpm} / 100 \mathrm{~cm}^{2} \text { (fixed-measurement } \\
\text { mode) }\end{array}$ \\
\hline Beta and detection range & $\begin{array}{l}5,000 \text { to } 1,000,000 \mathrm{dpm} / 100 \mathrm{~cm}^{2} \text { (scanning mode), } \\
1,000 \text { to } 1,000,000 \mathrm{dpm} / 100 \mathrm{~cm}^{2} \text { (fixed-measurement } \\
\text { mode) }\end{array}$ \\
\hline Gamma and detection range & Responds to gamma, but not calibrated for quantification. \\
\hline
\end{tabular}

\begin{tabular}{|c|c|c|}
\hline Scan rate & Feet per minute & 5 \\
\hline \multirow[t]{4}{*}{ Limitations related to } & Contamination & Yes \\
\hline & Pipe geometry & 2" to 3" diameter piping (including piping with bends). \\
\hline & Pipe bends & Yes \\
\hline & Other & $\begin{array}{l}\text { Pulled through piping with attached cables, useful for beta } \\
\text { energies }>50 \mathrm{keV}\end{array}$ \\
\hline
\end{tabular}


TECHNOLOGY SURVEY FOR DECONTAMINATION

OF INTERNAL AND EXTERNAL SURFACES OF PIPES

\begin{tabular}{|l|l|l|}
\hline Vendor & Name & Scientific Ecology Group, Inc. \\
\hline & Address & 1560 Bear Creek Road \\
\hline & P.O. Box. 230 \\
\hline & Oak Ridge, TN 37830 \\
\hline
\end{tabular}

\begin{tabular}{|l|l|l|}
\hline Contact & Name & Don Neely \\
\hline & Phone & $(423) 376-8237$ \\
\hline Fax & $(423) 376-8297$ \\
\hline
\end{tabular}

\begin{tabular}{|l|l|l|}
\hline Technology & Name & SN-050-6K \\
\hline Description & $\begin{array}{l}\text { Flexible detector assembly consisting of six 0.5" diameter } \\
\text { GM detectors enclosed in "ball" housings. Assembly } \\
\text { detection area } 7.6 \mathrm{~cm}^{2}\end{array}$ \\
\cline { 2 - 3 } & Geiger Muller $(\mathrm{GM})$ \\
\hline Setector type & Total alpha and total beta-gamma \\
\hline Spectrometric capabilities & \\
\hline Utilities required & \\
\hline
\end{tabular}

\begin{tabular}{|l|l|l|}
\hline Demonstration & Site & Fort St. Vrain Nuclea Facility Decommissioning. \\
\hline Results & $\begin{array}{l}\text { Performed characterization and final surveys of 1" diameter } \\
\text { plant system piping with bends (up to } 90^{\circ} \text { elbows) }\end{array}$ \\
\hline
\end{tabular}

\begin{tabular}{|l|l|l|}
\hline Applicable to pipe & External surface & No \\
\hline & Internal surface & Yes \\
\hline & Length & Up to 50 feet \\
\hline Diameter & 1 inch \\
\hline
\end{tabular}

\begin{tabular}{|l|l|l|}
\hline Applicable to radiation & Alpha and detection range & $\begin{array}{l}1,000 \text { to } 1,000,000 \mathrm{dpm} / 100 \mathrm{~cm}^{2} \text { (fixed-measurement } \\
\text { mode) }\end{array}$ \\
\hline Beta and detection range & $\begin{array}{l}1,000 \text { to } 1,000,000 \mathrm{dpm} / 100 \mathrm{~cm}^{2} \text { (fixed-measurement } \\
\text { mode) }\end{array}$ \\
\cline { 2 - 3 } & Gamma and detection range & Responds to gamma, but not calibrated for quantification \\
\hline
\end{tabular}

\begin{tabular}{|c|c|c|}
\hline Scan rate & Feet per minute & $\mathrm{N} / \mathrm{A}$ \\
\hline \multirow[t]{4}{*}{ Limitations related to } & Contamination & Yes \\
\hline & Pipe geometry & 1" diameter piping with bends (including elbows) \\
\hline & Pipe bends & Yes \\
\hline & Other & $\begin{array}{l}\text { Pulled through piping with attached cables, limited } \\
\text { scanning ability due to small detection area (more } \\
\text { applicable for incremented fixed point measurements in } \\
\text { piping), useful for beta energies }>50 \mathrm{keV}\end{array}$ \\
\hline
\end{tabular}


TECHNOLOGY SURVEY FOR DECONTAMINATION

OF INTERNAL AND EXTERNAL SURFACES OF PIPES

\begin{tabular}{|l|l|l|}
\hline Vendor & Name & Scientific Ecology Group, Inc. \\
\hline & Address & 1560 Bear Creek Road \\
\cline { 2 - 2 } & P.O. Box. 230 \\
\cline { 2 - 2 } & Oak Ridge, TN 37830 \\
\hline
\end{tabular}

\begin{tabular}{|l|l|l|}
\hline Contact & Name & Don Neely \\
\hline & Phone & (423) 376-8237 \\
\cline { 2 - 3 } & Fax & $(423) 376-8297$ \\
\hline
\end{tabular}

\begin{tabular}{|l|l|l|}
\hline Technology & Name & SN-050-8K \\
\hline & Description & $\begin{array}{l}\text { Flexible detector assembly consisting of eight 0.5" diameter } \\
\text { GM detectors enclosed in "ball" housings. Assembly } \\
\text { detection area } 10.1 \mathrm{~cm}^{2}\end{array}$ \\
\cline { 2 - 3 } & Getector type & Geiger Muller (GM) \\
\hline & Spectrometric capabilities & Total alpha and beta-gamma \\
\cline { 2 - 3 } & Special features & \\
\hline Utilities required & \\
\hline
\end{tabular}

\begin{tabular}{|l|l|l|}
\hline Demonstration & Site & $\begin{array}{l}\text { Fort St. Vrain Nuclear Facility Decommissioning. } \\
\text { plant system piping with bends (up to } 90^{\circ} \text { bends) }\end{array}$ \\
\hline Results & diameter \\
\hline
\end{tabular}

\begin{tabular}{|l|l|l|}
\hline Applicable to pipe & External surface & No \\
\hline & Internal surface & Yes \\
\hline Length & Up to 50 feet \\
\hline & Diameter & 1 inch \\
\hline
\end{tabular}

\begin{tabular}{|l|l|l|}
\hline Applicable to radiation & Alpha and detection range & $\begin{array}{l}1,000 \text { to } 1,000,000 \mathrm{dpm} / 100 \mathrm{~cm}^{2} \text { (fixed-measurement } \\
\text { mode) }\end{array}$ \\
\hline Beta and detection range & $\begin{array}{l}1,000 \text { to } 1,000,000 \mathrm{dpm} / 100 \mathrm{~cm}^{2} \text { (fixed-measurement } \\
\text { mode) }\end{array}$ \\
\hline Gamma and detection range & Responds to gamma, but not calibrated for quantification \\
\hline
\end{tabular}

\begin{tabular}{|c|c|c|}
\hline Scan rate & Feet per minute & $\mathrm{N} / \mathrm{A}$ \\
\hline \multirow[t]{4}{*}{ Limitations related to } & Contamination & Yes \\
\hline & Pipe geometry & 1 " diameter piping with bend (including elbows) \\
\hline & Pipe bends & Yes \\
\hline & Other & $\begin{array}{l}\text { Pulled through piping with attached cables, limited } \\
\text { scanning ability due to small detection area (more } \\
\text { applicable for incremented fixed point measurements in } \\
\text { piping), useful for beta energies }>50 \mathrm{keV}\end{array}$ \\
\hline
\end{tabular}


TECHNOLOGY SURVEY FOR DECONTAMINATION

OF INTERNAL AND EXTERNAL SURFACES OF PIPES

\begin{tabular}{|l|l|l|}
\hline Vendor & Name & Scientific Ecology Group, Inc. \\
\hline & Address & 1560 Bear Creek Road \\
\hline & & P.O. Box. 230 \\
\cline { 2 - 3 } & Oak Ridge, TN 37830 \\
\hline
\end{tabular}

\begin{tabular}{|l|l|l|}
\hline Contact & Name & Don Neely \\
\hline & Phone & $(423) 376-8237$ \\
\hline & Fax & $(423) 376-8297$ \\
\hline
\end{tabular}

\begin{tabular}{|l|l|l|}
\hline Technology & Name & Ludlum Measurements, Inc. (LMI), 43-94 \\
\hline Description & $\begin{array}{l}\text { LMI developed 0.5" diameter cylindrical gas flow detector } \\
\text { used with SEG feveloped procedures/methods and } \\
\text { apparatus (background shields, centering collars, } \\
\text { calibration jigs) }\end{array}$ \\
\cline { 2 - 3 } & Gas Flow Proportional \\
\hline Spectrometric capabilities & Total alpha or total beta-gamma \\
\hline Special features & \\
\hline Utilities required & \\
\hline
\end{tabular}

\begin{tabular}{|l|l|l|}
\hline Demonstration & Site & Fort St. Vrain Nuclear Facility Decommissioning \\
\hline & Results & $\begin{array}{l}\text { Performed characterization and final surveys of plant } \\
\text { system piping from } 0.75^{\prime \prime} \text { to } 1.5^{\prime \prime} \text { diameter }\end{array}$ \\
\hline
\end{tabular}

\begin{tabular}{|l|l|l|}
\hline Applicable to pipe & External surface & No \\
\hline & Internal surface & Yes \\
\cline { 2 - 3 } & Length & Up to 25 feet \\
\cline { 2 - 3 } & Diameter & 0.75 to 1.5 inches \\
\hline
\end{tabular}

\begin{tabular}{|l|l|l|}
\hline Applicable to radiation & Alpha and detection range & $\begin{array}{l}3,000 \text { to } 1,000,000 \mathrm{dpm} / 100 \mathrm{~cm}^{2} \text { (scanning mode), } \\
1,000 \text { to } 1,000,000 \mathrm{dpm} / 100 \mathrm{~cm}^{2} \text { (fixed-measurement } \\
\text { mode) }\end{array}$ \\
\hline \multirow{2}{*}{ Beta and detection range } & $\begin{array}{l}3,000 \text { to } 1,000,000 \mathrm{dpm} / 100 \mathrm{~cm}^{2} \text { (scanning mode), } \\
1,000 \text { to } 1,000,000 \mathrm{dpm} / 100 \mathrm{~cm}^{2} \text { (fixed-measurement } \\
\text { mode) }\end{array}$ \\
\cline { 2 - 3 } & Gamma and detection range & Responds to gamma, but not calibrated for quantification. \\
\hline
\end{tabular}

\begin{tabular}{|l|l|l|}
\hline Scan rate & Feet per minute & 10 \\
\hline Limitations related to & Contamination & Yes \\
\hline & Pipe geometry & $0.75^{\prime \prime}$ to $1.5^{\prime \prime}$ diameter \\
\cline { 2 - 3 } & Pipe bends & No \\
\cline { 2 - 3 } & Other & $\begin{array}{l}\text { Pushed/pulled through piping with attached cables, useful } \\
\text { for beta energies }>50 \mathrm{keV}\end{array}$ \\
\hline
\end{tabular}




\section{TECHNOLOGY SURVEY FOR DECONTAMINATION \\ OF INTERNAL AND EXTERNAL SURFACES OF PIPES}

\begin{tabular}{|l|l|l|}
\hline Vendor & Name & Scientific Ecology Group, Inc. \\
\hline & Address & 1560 Bear Creek Road \\
\hline \multirow{2}{*}{} & P.O. Box. 230 \\
\cline { 2 - 3 } & Oak Ridge, TN 37830 \\
\hline
\end{tabular}

\begin{tabular}{|l|l|l|}
\hline Contact & Name & Don Neely \\
\hline & Phone & $(423) 376-8237$ \\
\hline Fax & $(423) 376-8297$ \\
\hline
\end{tabular}

\begin{tabular}{|l|l|l|}
\hline Technology & Name & Ludlum Measurements, Inc. (LMI) 43-98 \\
\hline & Description & $\begin{array}{l}\text { LMI developed 1.5" diameter cylindrical gas flow detector } \\
\text { used with SEG developed procedures/methods and } \\
\text { appazarus (background shieids, centering collars, } \\
\text { calibration jigs) }\end{array}$ \\
\cline { 2 - 3 } & Gas Flow Proportional \\
\hline Detector type & Total alpha or total beta-gamma \\
\hline Spectrometric capabilities & Special features & \\
\hline Utilities required & \\
\hline
\end{tabular}

\begin{tabular}{|l|l|l|}
\hline Demonstration & Site & Fort St. Vrain Nuclear Facility Decommissioning \\
\hline Resuits & $\begin{array}{l}\text { Performed characterization and final surveys of plant } \\
\text { system piping form 2" to 3" diameter }\end{array}$ \\
\hline
\end{tabular}

\begin{tabular}{|l|l|l|}
\hline Applicable to pipe & External surface & No \\
\hline & Internal surface & Yes \\
\hline Length & Up to 25 feet \\
\hline Diameter & 2 to 3 inches \\
\hline
\end{tabular}

\begin{tabular}{|l|l|l|}
\hline Applicable to radiation & Alpha and detection range & $\begin{array}{l}3,000 \text { to } 1,000,000 \mathrm{dpm} / 100 \mathrm{~cm}^{2} \text { (scanning mode), } \\
1,000 \text { to } 1,000,000 \mathrm{dpm} / 100 \mathrm{~cm}^{2} \text { (fixed-measurement } \\
\text { mode) }\end{array}$ \\
\hline Beta and detection range & $\begin{array}{l}3,000 \text { to } 1,000,000 \mathrm{dpm} / 100 \mathrm{~cm}^{2} \text { (scanning mode), } \\
1,000 \text { to } 1,000,000 \mathrm{dpm} / 100 \mathrm{~cm}^{2} \text { (fixed-measurement } \\
\text { mode) }\end{array}$ \\
\hline Gamma and detection range & \begin{tabular}{l} 
Responds to gamma, but not calibrated for quantification \\
\hline
\end{tabular}
\end{tabular}

\begin{tabular}{|l|l|l|}
\hline Scan rate & Feet per minute & 10 \\
\hline Limitations related to & Contamination & Yes \\
\hline & Pipe geometry & $2 "$ to 3" diameter piping \\
\cline { 2 - 3 } & Pipe bends & No \\
\cline { 2 - 3 } & Other & $\begin{array}{l}\text { Pushed/Pulled through piping with attached cables, useful } \\
\text { for beta energies }>50 \mathrm{keV}\end{array}$ \\
\hline
\end{tabular}




\section{TECHNOLOGY SURVEY FOR DECONTAMINATION \\ OF INTERNAL AND EXTERNAL SURFACES OF PIPES}

\begin{tabular}{|l|l|l|}
\hline Vendor & Name & Scientific Ecology Group, Inc. \\
\hline \multirow{2}{*}{ Address } & 1560 Bear Creek Road \\
\hline & P.O. Box. 230 \\
\cline { 2 - 2 } & Oak Ridge, TN 37830 \\
\hline
\end{tabular}

\begin{tabular}{|l|l|l|}
\hline Contact & Name & Don Neely \\
\hline & Phone & (423) 376-8237 \\
\hline & Fax & $(423) 376-8297$ \\
\hline
\end{tabular}

\begin{tabular}{|l|l|l|}
\hline Technology & Name & TLD Strings \\
\hline Description & $\begin{array}{l}\text { TLDs attached to cables using specialized procedures/ } \\
\text { methods to assess contamination in 1" to 2" diameter } \\
\text { piping with bends }\end{array}$ \\
\hline & TLD \\
\hline Detector type & Spectrometric capabilities & Total beta-gamma \\
\hline Special features & Ltilities required & \\
\hline
\end{tabular}

\begin{tabular}{|l|l|l|}
\hline Demonstration & Site & Fort St. Vrain Nuclear Facility Decommissioning \\
\hline Results & $\begin{array}{l}\text { Performed characterization and final surveys of 1" to 2" } \\
\text { diameter concrete embedded piping with bends (up to } 90^{\circ} \\
\text { elbows) }\end{array}$ \\
\hline
\end{tabular}

\begin{tabular}{|l|l|l|}
\hline Applicable to pipe & External surface & No \\
\hline & Internal surface & Yes \\
\cline { 2 - 3 } & Length & $\begin{array}{l}\text { Previously used up to } 100 \text { feet (greater lengths feasible, } \\
\text { provided installation is possible) }\end{array}$ \\
\hline Diameter & 1 to 2 inches \\
\hline
\end{tabular}

\begin{tabular}{|l|l|l|}
\hline Applicable to radiation & Alpha and detection range & N/A \\
\hline & Beta and detection range & $>3,000 \mathrm{dpm} / 100 \mathrm{~cm}^{2}$ \\
\cline { 2 - 3 } & Gamma and detection range & Respond to gamma, but not calibrated for quantification \\
\cline { 2 - 3 }
\end{tabular}

\begin{tabular}{l|l|l|}
\hline Scan rate & Feet per minute & N/A \\
\hline Limitations related to & Contamination & Yes \\
\hline & Pipe geometry & 1 " to 2" diameter piping with bends (including elbows) \\
\cline { 2 - 3 } & Pipe bends & Yes \\
\cline { 2 - 3 } & $\begin{array}{l}\text { Other } \\
\text { waiting determined exposure periods, TLDs are removed } \\
\text { for processing. Long exposure periods required for low } \\
\text { sensitivity. Useful for beta energies }>50 \mathrm{keV}\end{array}$ \\
\hline
\end{tabular}


TECHNOLOGY SURVEY FOR DECONTAMINATION

OF INTERNAL AND EXTERNAL SURFACES OF PIPES

\begin{tabular}{|l|l|l|}
\hline Vendor & Name & Rad Elec Inc. \\
\hline \multirow{2}{*}{ Address } & $5714-C$ Industry Lane \\
\cline { 2 - 3 } & & Frederick, MD 21704 \\
\hline
\end{tabular}

\begin{tabular}{|l|l|l|}
\hline Contact & Name & Paul Kotrappa \\
\hline & Phone & (301) 694-0011 \\
\hline & Fax & (301) 694-0013 \\
\cline { 2 - 3 }
\end{tabular}

\begin{tabular}{|l|l|l|}
\hline Technology & Name & E-PERM \\
\hline & Description & Electrect Ion Chamber \\
\cline { 2 - 3 } & Detector type & $\begin{array}{l}\text { Passive Integrating Ionization Chambers using Electrects } \\
\text { as detectors }\end{array}$ \\
\hline Spectrometric capabilities & No spectrometric capabilities \\
\hline Special features & \\
\hline Utilities required & \\
\hline
\end{tabular}

\begin{tabular}{|l|l|l|}
\hline Demonstration & Site & Oak Ridge National Laboratory. \\
\hline \multirow{2}{*}{ Results } & $\begin{array}{l}\text { Capable of detecting levels of }<2.2 \mathrm{dpm} / \mathrm{cm}^{2} \text { of alpha } \\
\text { activity on surfaces and in pipe interiors }\end{array}$ \\
\hline
\end{tabular}

\begin{tabular}{|l|l|l|}
\hline Applicable to pipe & External surface & Yes \\
\hline & Internal surface & Yes \\
\hline Length & Up to 10 feet \\
\hline Diameter & Any \\
\hline
\end{tabular}

\begin{tabular}{|l|l|l|}
\hline Applicable to radiation & Alpha and detection range & $2.2 \mathrm{dpm} / \mathrm{cm}^{2}$ of alpha activity \\
\hline & Beta and detection range & $\begin{array}{l}\text { Depends upon energy example. Tritium pipe } \\
\text { contamination of } 2200 \mathrm{dpm} / \mathrm{cm}^{2}\end{array}$ \\
\cline { 2 - 3 } & Gamma and detection range & N/A \\
\hline
\end{tabular}

\begin{tabular}{|c|c|c|}
\hline Scan rate & Feet per minute & N/A. Passive detector \\
\hline \multirow[t]{4}{*}{ Limitations related to } & Contamination & Cannot distinguish Fixed or Removable \\
\hline & Pipe geometry & Could cause efficiency loss if not straight pipe \\
\hline & Pipe bends & Could cause efficiency loss, need calibration \\
\hline & Other & \\
\hline
\end{tabular}


TECHNOLOGY SURVEY FOR DECONTAMINATION

OF INTERNAL AND EXTERNAL SURFACES OF PIPES

\begin{tabular}{|l|l|l|}
\hline Vendor & Name & Rad Elec Inc. \\
\hline \multirow{2}{*}{ Address } & 5714-C Industry Lane \\
\cline { 2 - 3 } & & Frederick, MD 21704 \\
\hline
\end{tabular}

\begin{tabular}{|l|l|l|}
\hline Contact & Name & Paul Kotrappa \\
\hline \multirow{4}{*}{} & Phone & $(301) 694-0011$ \\
\hline Fax & $(301) 694-0013$ \\
\cline { 2 - 3 }
\end{tabular}

\begin{tabular}{|l|l|l|}
\hline Technology & Name & Ion Transfer Electrect Ion Chamber \\
\hline & Description & Fassive Integrating Electrect Ion Chamber \\
\cline { 2 - 3 } & Detector type & Electrect Ion Chamber \\
\cline { 2 - 3 } & Spectrometric capabilities & No \\
\cline { 2 - 3 } & Special features & $\begin{array}{l}\text { Based on measurement of ions produced by alpha } \\
\text { radiation }\end{array}$ \\
\cline { 2 - 3 } & Utilities required & Flowing air to transfer ions to the sensitive volume \\
\hline \multirow{2}{*}{ Demonstration performed } & Site & Oak Ridge National Laboratory \\
\hline \multirow{2}{*}{ Applicable to pipe } & Results & Calibrated and validated with test results \\
\hline & External surface & Yes \\
\hline & Internal surface & Yes to 10 feet \\
\cline { 2 - 3 } & Length & $6 "$ to $24 "$ diameter \\
\cline { 2 - 3 } & Diameter &
\end{tabular}

\begin{tabular}{|l|l|l|}
\hline Applicable to radiation & Alpha and detection range & $<2.2 \mathrm{dpm} / \mathrm{cm}^{2}$ of alpha activity \\
\hline & Beta and detection range & $\begin{array}{l}2200 \mathrm{dpm} / \mathrm{cm}^{2} \text { for tritium betas } \\
<2200 \mathrm{dpm} / \mathrm{cm}^{2} \text { for other beta emitters }\end{array}$ \\
\cline { 2 - 3 } & Gamma and detection range & $\mathrm{N} / \mathrm{A}$ \\
\hline
\end{tabular}

\begin{tabular}{|c|c|c|}
\hline Scan rate & Feet per minute & Entire pipe in 15 minutes at release rate \\
\hline \multirow[t]{4}{*}{ Limitations related to } & Contamination & Only detects alpha and beta contamination \\
\hline & Pipe geometry & None \\
\hline & Pipe bends & May need different calibration with reference source \\
\hline & Other & $\begin{array}{l}\text { Calibration or calibration validation required using a } \\
\text { reference source of the type of contamination being } \\
\text { measured }\end{array}$ \\
\hline
\end{tabular}

